\title{
The Okavango giant mafic dyke swarm (NE Botswana): its structural significance within the Karoo Large Igneous Province
}

\author{
Bernard Le Gall ${ }^{a}$, Gomotsang Tshoso a , Jérôme Dyment ${ }^{b}$, Ali Basira Kampunzu ${ }^{c}$, Fred \\ Jourdan $^{\text {d-e }}$, Gilbert Féraud ${ }^{d}$, Hervé Bertrand ${ }^{e}$, Charly Aubourg \\ ${ }^{\mathrm{a} C N R S-U M R}$ 6538, IUEM Brest, France \\ ${ }^{\mathrm{b}}$ CNRS-UMR 7097, Laboratoire Géosciences Marines Institut de Physique du Globe de Paris, Paris, \\ France \\ ${ }^{\mathrm{C}}$ University of Botswana, Gaborone, Botswana \\ ${ }^{\mathrm{d}}$ CNRS-UMR 6526 Geosciences Azur, Nice-Sophia Antipolis, France \\ ${ }^{\mathrm{e}} \mathrm{CNRS}-U M R$ 5570, ENS Lyon, France \\ ${ }^{\mathrm{f}}$ CNRS-UMR 7072, Cergy, France
}

\begin{abstract}
Quantitative structural data on the Okavango $\mathrm{N} 110^{\circ}$ E-trending giant mafic dyke swarm in the northern Karoo Large Igneous Province (LIP., NE Botswana) are based on >170 (exposed) and 423 (detected by ground magnetics) dykes on a ca. $80 \mathrm{~km}$-long section lying at high-angle to the densest zone of the dyke complex. This study partially covers also a second Karoo dyke swarm striking $\mathrm{N} 70^{\circ} \mathrm{E}$. Within each swarm, individual dykes are sub-vertical, parallel to the entire swarm. The average thickness of dykes within the two swarms is $18 \mathrm{~m}\left(\mathrm{~N} 110^{\circ}\right)$ and $27 \mathrm{~m}\left(\mathrm{~N} 70^{\circ}\right)$, but with marked variations in the $\mathrm{N} 110^{\circ} \mathrm{E}$ dyke system correlated to the lithology of host-rocks (Archaean metamorphic basement vs Permo-Triassic sedimentary cover). The frequency of $\mathrm{N} 110^{\circ} \mathrm{E}$ Karoo dykes increases markedly in two densest zones (ca. $10 \mathrm{~km}$-wide each) on both sides and along an identified Proterozoic N110 ${ }^{\circ}$ E-trending dyke zone. The cumulative width of Karoo dykes (87\% of the total population) is $6315 \mathrm{~m}$ along reference section, implying an average dyke-induced crustal dilatation of $12.2 \%$ on the $52 \mathrm{~km}$-long section projected perpendicular to the $\mathrm{N} 110^{\circ}$ trend of the dyke swarm. During the Karoo igneous event, crustal extension in NE Botswana is primarily accommodated through dyke intrusion rather than normal faulting. The two sets of coeval Karoo dyke swarms documented in NE Botswana occur along preexisting basement structures, reactivated as oblique $\left(\mathrm{N} 110^{\circ} \mathrm{E}\right)$ and pure extension $\left(\mathrm{N} 70^{\circ} \mathrm{E}\right)$ fractures during a single $\mathrm{N} 160^{\circ} \mathrm{E}$-directed extension. Because of the inherited origin of the two giant Karoo dyke swarms in NE Botswana, the Nuanetsi radiating dyke system can no longer be taken for a proof of a deep mantle plume.
\end{abstract}

Keywords : Structure, Giant dyke swarm, Okavango, Karoo magmatic province.

\section{Introduction}


During the two last decades, igneous dyke swarms have received considerable attention in both intraplate Large Igneous Provinces (LIP) and in magmatically profuse passive margins (White, 1992; Geoffroy, 2001; Callot et al., 2001 and references therein). This interest results from the ability of dyke swarms to supply informations on (1) the relative timing of deformation versus igneous activity; (2) the prevalent stress field during magma emplacement and; (3) the amount of crustal extension during dyke emplacement. Therefore, dyke swarms are key kinematic indicators in stretched continental crusts (Ernst et al., 1995). In old magmatic provinces, dyke swarms provide also structural and magmatic records for the roots of deeply eroded intrusive systems. This is particularly true for the Jurassic evolution of the Karoo-Antarctica Large Igneous Province (KA-LIP hereafter) in relation with Gondwana supercontinent dispersal (Fig. 1). Previous kinematic models of the KA-LIP were based on either petrological data (e.g. Elliott, 1992; Brewer et al., 1992; Storey et al., 1992) or general geodynamical criteria derived from the spatial distribution of volcanic complexes (Burke and Dewey, 1972; White and McKenzie, 1989). Particularly, the large-scale radiating dyke systems centered in the Nuanetsi area (Fig. 1) are usually regarded as a convincing evidence for a mantle plume beneath the Karoo igneous province (White and McKenzie, 1989; Campbell and Griffiths, 1990; Cox, 1992). However, detailed geochronological, petrological, and structural data on the Lebombo (NS), Olifants River $\left(\mathrm{N} 20^{\circ}\right)$, Limpopo (N70 ${ }^{\circ}$ ) and Okavango $\left(\mathrm{N} 110^{\circ}\right)$ dyke swarms forming the Nuanetsi triple junction-like pattern are lacking to firmly establish their synchronous and cogenetic emplacement as expected in a « mantle plume » model.

This paper presents the first detailed quantitative structural study of two arms of the Nuanetsi triple system, i.e. the $\mathrm{N} 110^{\circ} \mathrm{E}$-trending Okavango swarm (N110\% ODS) and part of the $\mathrm{N} 70^{\circ} \mathrm{E}$ trending Limpopo swarm (N70\%LDS), as exposed in NE Botswana. Structural field measurements are integrated with : (1) ground- and aero-magnetic data, and (2) geochronological-petrological data from a $80 \mathrm{~km}$-long section (52 km-long once projected perpendicular to the main trend of the $\mathrm{N} 110 \%$ ODS), across the highest dyke density zone of the swarm. Compiling these dataset offers the possibility to unravel the anatomy of a giant mafic dyke swarm and to investigate specific problems dealing with : (1) individual dyke geometry (e.g. strike, dip, width), (2) the dyke opening direction, (3) dyke spatial distribution and frequency and; (4) relations between N110\%/ODS and N70\%/LDS dyke swarms, with particular emphasis on geometric and chronologic relations of fracture/dyke swarms and related paleostress fields in the northern Karoo igneous province. Recent geochronologic data on dykes exposed along N110\%/ODS and N70\%/LDS (Le Gall et al., 2002; Jourdan et al., 2004) allow us to properly constrain the role of Precambrian structures on Karoo dyke emplacement, providing new insights into the mantle dynamics during the tectonic and magmatic development of the Karoo LIP.

\section{Geological framework}

From aeromagnetic records (Reeves, 2000), dykes in NE Botswana can be divided spatially into two principal domains on the basis of dyke orientation (Figs. 1, 2). The $<100 \mathrm{~km}$-wide Okavango dyke swarm (N110\%ODS) has a remarkably constant strike of N110 ${ }^{\circ} \mathrm{E}$ over $\sim 1500 \mathrm{~km}$, with no evidence of cartographic deflection around concealed intrusive centers at depth. The southwestern tip of the Limpopo dyke swarm (N70\%/LDS) exposed in NE Botswana is a 50 kmwide dyke zone ending abruptly to the WSW. Over most of their lengths, the two dyke swarms are deeply covered by Kalahari sands in NE Botswana. They are partially exposed in the easternmost part of the country where they cut across basement crystalline rocks to the west, and Karoo Permo- 
Jurassic sedimentary and volcanic rocks in the Tuli basin further east (Fig. 2). Country-rocks are mainly Neo-Archaean granulite to amphibolite facies gneisses and granitoids of the Limpopo belt. These Archaean metamorphic terrains were reactivated during the Palaeoproterozoic (e.g. McCourt and Armstrong, 1998), and their complex deformational history is shown by polyphase folded ductile fabrics disrupted by variously-trending shear zones and fracture networks.

In $\mathrm{NE}$ Botswana, $\mathrm{N} 110^{\circ} \mathrm{E}$ and $\mathrm{N} 70^{\circ} \mathrm{E}$ Karoo dyke swarms and related lavas are exclusively composed of mafic rocks, i.e. basalts, dolerites and minor gabbros (Tshoso et al., 2004; Jourdan et al., 2004). Ar-Ar plagioclase dating of these Karoo dykes yield plateau ages of ca.179 Ma (Le Gall et al., 2002; Jourdan et al., 2004) for both sets. There is no across-strike age variation within the 53 Karoo-related dolerite dykes sampled along the $80 \mathrm{~km}$-long Shashe section (Jourdan et al., 2004). Therefore, the Jurassic dykes of the N110\%ODS are assumed to have intruded the crust over a short time span of 1-2 Ma, in agreement with previous others radiometric age data for lavas in the northern Karoo LIP (2000; Jones et al., 2001).

\section{Data acquisition}

The present work is interested in the broad structure of the two dyke swarms, but it also concentrates on the form and structure of individual dykes. Exposures are usually limited in extent, hamperring the investigation of 3D-geometry and along-strike characteristics of individual dykes. However, exceptionally good exposures at a few localities (e.g. Shashe Dam, Thune River, Fig. 2a) allow a detailed mapping of the dyke system, and vertical sections of dykes were documented in a few quarries (e.g. Francistown and Phoenix, Fig. 2a). The corner-stone of our investigation of the giant dyke swarms in NE Botswana is the $\approx 80 \mathrm{~km}$-long Shashe (dry) river traverse that cuts at high angle through the densest zone of the N110\%ODS (Fig. 2b). A series of exposed sections along the Shashe reference transect (Fig. 3b) allow systematic structural measurements of the dyke population (strike, dip, width). In addition, estimates of dyke-induced crustal dilatation is calculated on the 52 $\mathrm{km}$-long section projected perpendicular to the trend of the swarm, and which represents $\sim 87 \%$ of the total width $(60 \mathrm{~km})$ of the highest dyke density zone of the N110\%/ODS (Fig. 2a).

Among 171 dykes identified along the exposed portions ( 58\%) of the Shashe profile (Fig. 3c), 153 dykes have been accurately measured (Table 1). However, a greater number of dykes (423) is detected along this profile using ground magnetics (Tshoso et al., 2004). The accuracy of the data in this paper is $0.5 \mathrm{~m}$ for the dyke width and $1^{\circ}$ for their strike and dip.

Ar/Ar dating and petrological data (Le Gall et al., 2002; Jourdan et al., 2004) unravel 8 N110 ${ }^{\circ}$-striking Proterozoic dykes within the 53 dykes dated along the Shashe transect. The $\mathrm{N} 110 \%$ ODS is thus a composite and polyphase dyke complex estimated to include about $87 \%$ of Jurassic dykes and 13\% of Proterozoic dykes. The $52 \mathrm{~km}$-long projected section has been subdivided into four distinct segments (Fig. 3c). Identified Proterozoic dykes are restricted to a 22 km-long central zone, between Tati Siding and Chadibe (segment III in Fig. 3c). In this zone, Karoo dykes represent 70\% (26 dykes) versus 30\% (8 dykes) for Proterozoic dykes. The three other segments (I, II, and IV) apparently consist of Karoo dykes; but, some uncertainties exist about the poorly-exposed $10 \mathrm{~km}$-long Shashe Dam-Tati Siding segment (II) where only two Karoo dykes were sampled.

Applying the four corresponding ratios (i.e. 100, 100, 70, and 100\% of Karoo dykes for segments I, II, III, and IV) to the entire dyke population (423 data) suggests that the Okavango giant 
dyke swarm may comprise around 370 Karoo dykes (ca. 87\%) along the $80 \mathrm{~km}$-long Shashe transect. In the text, the term N110\%ODS will only refer to the Karoo part of the Okavango composite dyke complex

Field investigations were also conducted in the Tsetsebjwe (south) and Tuli (east) areas (Fig. 2a) to assess the role of country-rock lithology on the across- and along-strike variations in structural styles of the dykes when they cut across Archaean crystalline basement (Tsetsebjwe) and sedimentary Karoo terrain (Tuli basin). The limited number of dykes measured in these two areas cannot be statistically representative for the regional patterns, but the quantitative parameters (width, total dilatation) on these dykes may be compared to those of the Jurassic $\mathrm{N} 110^{\circ} \mathrm{E}$ dykes along the Shashe reference section.

\section{Geometry of dykes}

Most of the geometrical data constraining Karoo dyke emplacement mechanism are acquired on horizontal surfaces, with a few vertical sections documented in Francistown and Phoenix quarries (Fig. 2a). Strike and length of the dykes are extensively analyzed using both new and previous data from geological maps covering the densest zones of the $\mathrm{N} 110^{\circ} \mathrm{E}$ and $\mathrm{N} 70^{\circ} \mathrm{E}$ dyke swarms (Fig. 4).

\subsection{Strike}

The dyke networks on the Shashe and Tsetsebjwe 1:125 000 geological maps are derived from aerial photographs (Aldiss, 1981, 1986). The existence of two chronologically unrelated dyke populations with the same $\mathrm{N} 110^{\circ} \mathrm{E}$ trend along the Shashe reference section puts some limitations to the statistical analysis of the mapped dykes. However, this approach is attempted because of the high estimated percentage (87\%) of Karoo dykes (Table 1). The distribution of dykes in the two dyke swarms in the N110\%/ODS Shashe (628 dykes) and the N70\%/LDS Tsetsebjwe (201 dykes) areas indicates a preferred dyke orientation within each swarm. About $70 \%$ of dykes in the ODS are within $10^{\circ}$ of parallelism with the $\mathrm{N} 110^{\circ} \mathrm{E}$ trend of the swarm envelop. This is confirmed by the statistical analysis of 105 dykes measured on the field along the Shashe section that shows $76 \%$ of dykes striking in the interval $\mathrm{N} 100-\mathrm{N} 120^{\circ}$. A stronger parallelism for the dykes in the $\mathrm{N} 70^{\circ} / \mathrm{LDS}$ is shown by $95 \%$ of dykes oriented between $\mathrm{N} 60^{\circ}-\mathrm{N} 80^{\circ}$.

\subsection{Length}

Karoo dyke length in the Shashe and Tsetsebjwe areas ranges from $\sim 1-18 \mathrm{~km}$ for $\mathrm{N} 110^{\circ} / \mathrm{ODS}$ and 1-14 km for N70\%/LDS. A similar mean dyke length of $3.0 \mathrm{~km}$ is obtained for both swarms.

\subsection{Dip}

The dip of 82 dykes (Jurassic and Proterozoic dykes undifferentiated) along the Shashe section indicates that $\sim 91 \%$ of dykes are vertical, and the remaining $9 \%$ are within $30^{\circ}$ of the vertical (Fig. 4a). Field observations show that the inclined Proterozoic and Jurassic dykes were injected along preexisting steeply-dipping reverse faults striking at ca. $\mathrm{N} 110^{\circ} \mathrm{E}$.

Karoo dykes exposed along the Thune river, at the southern margin of the Tuli basin, dips consistently $70-80^{\circ} \mathrm{S}$, cutting across Permo-Triassic Karoo strata that are shallowly-inclined $\left(\sim 20^{\circ}\right)$ to the $\mathrm{N}$ (Fig. 4c). The entire dyke/host-rock system is dissected by a dense array of dyke-parallel normal faults that preferentially reactivate dyke margins with a dominantly dip-slip component (Fig. 
6b). The dipping attitude of Karoo dykes in the Tuli basin is thus likely to result from fault-induced rotation that clearly post-dates dyke emplacement.

\subsection{Shape of dykes}

The best dyke exposures in the basement area (Shashe Dam) and the Tuli Karoo basin (Thune river section) display significant variations for the 2D dyke geometry in the N110\%/ODS.

The Karoo dykes in the Tuli half-graben basin cut through sedimentary rocks lying along its southern flexural margin, close to the contact with the overlying Karoo lava pile (Fig. 5a). In a $150 \mathrm{x}$ $200 \mathrm{~m}$ area along the Thune river, grit strata plunging shallowly to the north are cut by narrow (average 1-2 m-thick) connected dykes (12 dykes) that are symmetrically distributed on both sides of a 20 m-wide gabbroic body striking $\mathrm{N} 105^{\circ} \mathrm{E}$ (Fig. 5b). The dykes form a braided dyke system, according to the classification of Hoek (1991), with relatively smooth dyke trajectories (Fig. 5b). $80 \%$ of the 56 dyke azimuths measured in this area (with several data on each individual dyke) lie between $\mathrm{N} 90-120^{\circ}$ (Fig. 5c). The alternation of dykes and sedimentary rocks leads locally to elongate country-rock bodies engulfed by the mafic dykes.

A wider azimuth range typifies dykes of the N110\%ODS cutting through Archaean crystallyne basement in the western part of the study area. The distribution of 6 closely-spaced Karoo dykes/dykelets in the Phoenix quarry, $50 \mathrm{~km}$ E of the Shashe section (Fig. 2a), is shown in Figure 6a. Strike changes of ca $45^{\circ}$ originate from predominantly right side-steps (Fig. 6b) related to a set of fractures striking in the azimuth N75-125, although 70\% of dykes trend N90-110 .

A greater dyke azimuth dispersal occurs in an array of 3 major segmented dykes cutting through Archaean granitoid host-rocks in the Shashe Dam sector (Figs. 2a, 6c). The rose diagram of Figure 6e shows 34 segments of the 3 dykes striking between $\mathrm{N} 40^{\circ} \mathrm{E}$ and $\mathrm{N} 140^{\circ} \mathrm{E}$ with a bimodal peak at $\mathrm{N} 80^{\circ} \mathrm{E}$ and $\mathrm{N} 140^{\circ} \mathrm{E}$.

The 3 dykes in the Shashe Dam area display a zig-zag geometry in plan-view, as defined elsewhere by Hoek (1991). For example, the walls of dyke labelled ' $c$ ' in Figures 6c, d involve $N 70^{\circ} \mathrm{E}$ to $\mathrm{N} 140^{\circ} \mathrm{E}$ segments of similar length and width, with predominance of right side-steps. These connected dyke segments locally follow pre-existing fractures in the gneissic host-rocks (Fig. 6d).

\subsection{Width}

The width of $\mathrm{N} 110 \%$ ODS Karoo dykes is constrained using; (1) field measurements providing an incomplete, but accurate dataset and; (2) ground magnetic records supplying a complete dataset, but with uncertainty on the age of individual dyke.

Field measurements were principally acquired on dykes intruding the Archaean crystalline basement along the Shashe transect. For each dyke, the width is measured normal to the main strike of the dyke. Where eroded or not exposed, the contact between the dyke and its host-rock can usually be located within $0.5 \mathrm{~m}$. Individual dyke width varies from a few $\mathrm{cm}$ up to $60 \mathrm{~m}$, and only few examples of Karoo dykes have a thickness $<1 \mathrm{~m}$. The dyke width estimates from ground magnetic records is deduced from the shape of magnetic anomalies (Tshoso, 2003).

Dyke width data for the Shashe section include 146 field and 423 magnetic width data that both define asymmetric curves on the histograms of Figures $7 b_{1}, b_{2}$. The geophysical width data displays a mode in the interval 10-15 $\mathrm{m}$, whereas the field data shows a bimodal distribution with two maxima at 10-15 and 20-25 m. Because of the composite origin (Jurassic and Proterozoic dykes) of the N110\%/ODS, the mean width of Karoo dykes can be estimated in various ways as a function of 
the dyke population (field measurements or ground magnetic records) selected in the Shashe section (Table 2). The calculated arithmetic mean widths for the total population of dykes recorded using ground magnetics or field measurements are $17.5 \mathrm{~m}$ and $17.6 \mathrm{~m}$, respectively. However, these results are biased because $30 \%$ of dykes are Proterozoic in age in the central transect III. A presumably more accurate distribution of Karoo dyke widths is calculated using only dykes along the three transects I, II, and IV that are assumed to be mostly composed of Karoo dykes. The mean widths of 18.7, 18.0 and 17.0 m calculated from field measurements for transects I (30 dykes), II (5 dykes), and IV (30 dykes), respectively (Figs. $7 \mathrm{c}_{1}, \mathrm{e}_{1}$ ) is quite similar to the mean width of $20 \mathrm{~m}$ obtained using the 29 Karoo dykes dated at ca 179 Ma (Ar/Ar method) along the Shashe section (Jourdan et al., 2004). The mean dyke widths deduced from the magnetic anomalies are 12.8, 21.8, and $18 \mathrm{~m}$ for transects I (87 dykes), II (57 dykes), and IV (92 dykes), respectively (Figs. $7 \mathrm{c}_{2}, \mathrm{~d}_{2}, \mathrm{e}_{2}$ ) (Tshoso, 2003), thus giving an average Karoo dyke width of $17 \mathrm{~m}$. However, this value should be an underestimate because it does not take into account the thickest dykes (partly Karoo in age) known to occur in the composite transect III.

The distribution of individual Karoo dyke width within the three transects I, II, and IV is illustrated in Figure 8 that shows : (1) the intricate and rapid alternation of both thin and thick dykes within each transect, and (2) the great number of thick ( $>20 \mathrm{~m}$ ) dykes to the North in transect IV (34 dykes) with respect to segments I (15 dykes) and II (24 dykes).

Comparing dyke width from the Shashe (146 dykes), Tuli (13 dykes), and Tsetsebjwe (13 dykes) areas is difficult because of the discrepancy in the number of measurements. Nevertheless, there is a clear trend of Karoo dyke width to increase from $1.3 \mathrm{~m}$ for $\mathrm{N} 110^{\circ} \mathrm{E}$ dykes intruding sedimentary rocks in the Tuli basin, to $18 \mathrm{~m}$ for $\mathrm{N} 110^{\circ} \mathrm{E}$ dykes cutting across Archaean basement in the Shashe area, up to $27 \mathrm{~m}$ for $\mathrm{N} 70^{\circ} \mathrm{E}$ dykes intruding crystalline basement in the Tsetsebjwe area.

\section{Spacing and dyke distribution}

The 2D-distribution of Karoo dykes in the N110\%/ODS is constrained using both field and ground magnetic data along the Shashe section. On well-exposed areas, field observations indicate that the N110\%/ODS consists of individual dykes, with very few apophyses, separated by large areas with no intervening mafic dykelets. However, a more continuous distribution of dykes is revealed by ground magnetic data. The frequency of Karoo dykes per $2 \mathrm{~km}$ interval has been calculated for each transect I, II, III and IV of the Shashe section by applying the corresponding Jurassic/total dyke ratios of $100 \%$ (I, II, IV) and $70 \%$ (II) (Fig. 12a). The histograms of Figures 9b, c show three highdensity dyke zones, 10 km-wide each, labeled X (108 dykes), Y (118 dykes), and Z (92 dykes), and two narrow intervening low-density dyke zones. The $\sim 20 \mathrm{~km}$-wide densest zone (Y) occurs in a central position, between Tati Siding and Chadibe, i.e. where Proterozoic dykes are documented. It also hosts the widest dyke $(60 \mathrm{~m})$ of the study area.

The frequency and spacing of Karoo dykes, expressed as the volume percentage of rocks composed of dykes, is used to infer the amount of dilatation along the Shashe reference section (Fig. 9c). Crustal dilatation (D) is obtained by projecting the dykes onto a line that is drawn perpendicular to the envelop of the swarm and dividing the cumulative dyke width by the length of the line (Gudmundsson, 1990b) :

$$
\mathrm{D}=\underline{\Sigma \mathrm{W} \times 100}
$$




\section{$\mathrm{L}$}

where $\mathrm{w}$ is the cumulate width of dykes, and $\mathrm{L}$ the length of the projected section.

The cumulative dyke width ( $\left.\sum \mathrm{w}\right)$ deduced from ground magnetic data (Tshoso et al., 2004) is 6315 $\mathrm{m}$. In terms of finite strain, it corresponds to a crustal dyke-induced dilatation of $12.2 \%$ in the 52 $\mathrm{km}$-long projected section. Extrapolating this value to the total width $(60 \mathrm{~km})$ of the highest dyke density zone suggests, at first approximation, a dyke-driven extension of $\sim 7300 \mathrm{~m}$ in the ODS. Figure 9c illustrates the inhomogeneous distribution of dilatation across the N110\%ODS. Transects with high dilatation of $17 \%$ on a $2 \mathrm{~km}$-long section at Tati Siding, $16 \%$ on a $4 \mathrm{~km}$-long section at Borolong, and $19 \%$ on a $2 \mathrm{~km}$-long section at Mattangwane alternate with lower dilatation transects of $<2 \%$ on $2 \mathrm{~km}$-long sections at Tonotha and S Tati Siding. For comparison, the average dilatation is $18 \%$ in the $1 \mathrm{~km}$-long profile across the N70\%/LDS system in the Tsetsebjwe area.

The inhomogeneous distribution of dyke-induced dilatation coincides with those of dyke frequency along the projected section (Figs. 9b, c). The two dyke zones X and Z, with dyke-related extension of $11 \%$ and $13.9 \%$, respectively, are symmetrically distributed on both sides of the composite zone Y hosting both Jurassic and Proterozoic dykes, where Karoo extension is $12.4 \%$.

\section{Kinematics of dyke emplacement}

\subsection{Dyke emplacement stages}

There are only a few case of multiple-stage dykes recording a repetition of the sequence fracture-dilatation-magma injection in the Karoo dykes in NE Botswana. The best example is observed in the Borolong area (see location in the section of Fig. 9a) where a 1m-thick dyke occurs in the central part of a 20 m-thick Karoo dyke and emits apophyses along cooling joints of the hostdyke. These relationships in sub-coeval dykes (with concordant $\mathrm{Ar} / \mathrm{Ar}$ ages within analytical errors) indicate that distinct incremental dilatation stages locally occur during the emplacement of the N110\%/ODS.

Evidence for forceful emplacement of dykes are very rare. Most individual dykes show a welldeveloped centimetric aphyric chilled margin and enclose very few crustal xenoliths. Furthermore, there are no significant brecciated wall rocks nor distortion in the intruded rocks.

\subsection{Structural control}

Whether dykes occupy preexisting fractures or generate their own fractures is a longstanding debate (Delaney et al., 1986). This problem is emphasized when host-rocks are part of a crystalline basement terrain having recorded a complex polyphase brittle-ductile history, as is the case for Archaean rocks intruded by Karoo dykes in NE Botswana. However, both types of fractures are suggested to exist in the N110\%ODS from regional geology and field relations between dykes and fractures in the Shashe section.

The highly-deformed Archaean crystalline basement along the Shashe section displays ductile fabrics intensely disrupted by variously-oriented brittle fractures, in a steep attitude, including $\mathrm{N} 110^{\circ}$-trending structures that parallel the ODS trend. Fractures filled with sericite/chlorite are likely to be Precambrian structures. Kinematic indicators observed on the $\mathrm{N} 110^{\circ} \mathrm{E}$ inferred basement surfaces record various origins, including extensional joints, strike-slip 
faults, reverse fault-related fractures. Although locally abundant and favourably-oriented with regards to the presumed Karoo extension (see below), the limited lateral extent (usually $<1.0 \mathrm{~m}$ ) of most of these inherited structures makes it unlikely that they have served as fractures being subsequently dilated to form regional Karoo dykes.

More convincing evidence for the role of basement fabrics on Karoo dyke orientation in the N110\%/ODS are observed in the Shashe Moocke and Borolong areas (Fig. 3a). There, two stronglydeformed corridors, 1-2 km-wide each, enclose a dense array of vertical open fractures with a spacing generally $<1.0 \mathrm{~m}$. The constant attitude of these closely-spaced fractures, striking N100$110^{\circ} \mathrm{E}$ over a few $10^{\prime}$ s $\mathrm{m}$ within each fault zone, as well as their restricted distribution in the area hosting Proterozoic dykes (Transect III on Figure 3c), suggest that they are tensile fractures related to Proterozoic dyking. As these fractures do not occur systematically in the vicinity of exposed dykes, they could have developed beyond the tip zones of basement dykes lying just below the surface.

The influence of Proterozoic structures on Karoo dyke geometry was also established at a smaller scale in the Shashe Dam area (Fig. 6c). The narrow zigzag-shaped dyke named ' $c$ ' in Figure 6c displays connected segments with a wide range of fracture/dyke azimuths between $\mathrm{N} 40-140^{\circ} \mathrm{E}$. These trends strictly coincide with $\mathrm{N} 30-40^{\circ} \mathrm{E}$ ductile foliation planes and $\mathrm{N} 70-130^{\circ} \mathrm{E}$ brittle structures (joints and sericite-filled dextral faults) in the Archaean orthogneiss host-rocks.

The inherited origin of the fault/fracture system in the N70\%/LDS is much less clear. However, the coexistence of both Proterozoic (1 dyke; Ar/Ar plagioclase age) and Jurassic (2 dated dykes) in the Tsetsebjwe area (Jourdan et al., 2004) again suggests that reactivation of basement weak zones has partly controlled the emplacement of Karoo dykes within the N70\%/LDS.

The original relations between $\mathrm{N} 70^{\circ} \mathrm{E}$ and $\mathrm{N} 110^{\circ} \mathrm{E}$ Proterozoic dyke swarms remain poorly constrained because they are exposed in separate geographical areas.

\subsection{Dyke-related deformation}

The discrimination between dyke-generated and preexisting fractures can be made by comparing their abundance close to a given dyke with their regional abundance (Delaney et al. 1986) in both basement and sedimentary host-rocks.

In the Tuli basin, host-rocks consist of unmetamorphosed Permo-Triassic sedimentary strata, tilted to the north with consistent dips of ca. $20^{\circ}$ (Figs. 4c, d). The only clear deformation related to dyke injection in the grit/shale alternations are curved anastomosing joints, filled with white material.

The identification of brittle deformation structures induced by Karoo dykes in the basement is more difficult, but supportive evidences occur in two zones in the Shashe area. In the Francistown quarry (Figs. 2a, 10a), a 1.2 m-thick Karoo dyke which yielded a poorly-defined ${ }^{40} \mathrm{Ar} /{ }^{39} \mathrm{Ar}$ age of $173.2 \pm 2.8$ Ma., Le Gall et al., 2002), cuts across an Archaean tonalite. The crystalline host-rocks are intensely disrupted by a dense network of brittle joints, parallel to the dyke margins, that gradually decrease in density 2-3 $\mathrm{m}$ apart of the dyke. The symmetrically-distributed brittle fractures likely formed during dyke emplacement as wall-parallel tensile joints in the basement tonalitic rocks. 
A similar structural pattern occurs in the Shashe Dam section (Fig. 6c) where vertical dykeparallel joints are restricted to 3-4 m away of the southern margin of a 20 m-wide Karoo dyke ( $b_{2}$ in Fig. 6c, 10c). Preexisting basement strike-slip faults trend also $\mathrm{N} 110^{\circ} \mathrm{E}$ in this area (Fig. 6c).

Extensional faults spatially associated to Karoo dykes are restricted to the southern margin of the Tuli half-graben. Most fault planes (24 data) strike N95-115 ${ }^{\circ} \mathrm{E}$ (Fig. 4b), along steeply-inclined dyke walls (16 data, e.g. 66\%) and within the shallowly-dipping sedimentary strata (8 data). Fault surfaces are strongly striated (Fig. 4e), and the relations between dip of faults and pitches of striations indicate 66\% (16 data) normal dip-slip faults (Fig. 4b). Most of the remaining faults (8 data) show highly-plunging slickensides consistent with a slight sinistral component along the fault planes. From these structural observations, it is suggested that dominantly extensional fault is responsible for fault-block rotations in the Tuli basin and controlled the entire dyke/host-rocks system rotation, hence post-dating the emplacement of Karoo dykes.

\subsection{Direction of fracture opening and paleostress}

Dykes orientation cannot be directly used to infer paleostress directions when magmas are emplaced along pre-existing fractures that do not necessarily represent tensional structures perpendicular to the least compressional stress (Delaney et al. 1986). In such cases, other kinematic criteria, such as the opening direction of dykes as well as variations of dyke thickness, can be used to establish the direction of extension that prevails during dyke emplacement.

The dilatation direction can be determined from a variety of markers in dyke wall rocks (veins or side-steps). In the study area, dense Precambrian aplite-pegmatite veins in the granitoidgneiss country-rocks of the Shashe section was used to monitor the displacement caused by dyke emplacement. Most observations were done in horizontal sections, providing only the apparent (horizontal) direction of dilatation. The Karoo dyke exposed on a vertical section in the Francistown quarry (Fig. 10a), displays a shallowly-plunging component of dilatation (apparent plunge of $10^{\circ}$ to the S), indicating moderate sinistral shearing along the dyke wall during dyke opening.

At three localities shown on Fig. 3a, the finite direction (horizontal component) of opening of the $\mathrm{N} 110^{\circ}$ ODS dyke fractures is deduced from narrow $(<2 \mathrm{~m})$ Karoo dykes :

(1) In the Shashe Dam area, the segmented dyke labeled 'c' on Figure 6c displays numerous pairs of angular offsets that can be matched on opposite dyke walls (Figs. 11a, c). This method of reconstruction of the walls to their pre-intrusion position (Walker, 1987; Bussell, 1989) enables the identification of the dilatation vector that preferentially strikes $\mathrm{N} 160-165^{\circ} \mathrm{E}$, oblique to the $\sim \mathrm{N} 90^{\circ} \mathrm{E}$ trend of the dykes envelop. It thus appears that the invaded joint was not perpendicular to the least compressive regional stress, hence resulting in a small component of horizontal shear (sinistral) along the dyke margin during its emplacement.

(2) A nearly similar direction of dyke opening at $\mathrm{N} 170^{\circ} \mathrm{E}$ is obtained from a system of zigzag dykelets cutting granites in the Chadibe area with a broad $\mathrm{N} 90^{\circ} \mathrm{E}$ trend (Fig. 10e).

(3) Matching chlorite-filled basement veins on both sides of a $\mathrm{N} 120^{\circ} \mathrm{E}$ dylelet in the Shashe Mooke area (Fig. 10f) suggests also a $\mathrm{N} 170^{\circ} \mathrm{E}$ dilatation vector. Again, dyke-parallel sinistral shearing coeval with dilatation has operated during dyke injection, assuming that no lateral offset took place along the fracture prior to dyke intrusion. The oblique $\left(\sim \mathrm{N} 40^{\circ} \mathrm{E}\right)$ network of open fractures within the basaltic dyke is also likely to have formed as R-type Riedel fractures during sinistral shearing. 
Despite the limited number of data, the consistent $\mathrm{N} 160-170^{\circ} \mathrm{E}$ extension azimuth at three sites suggests that the $\mathrm{N} 110^{\circ} \mathrm{E}$ fracture network hosting Karoo magma in the ODS dilated as shear structures oblique to the regional extension. The N70 ${ }^{\circ}$-trending LDS to the south probably opened as pure extensional structures, orthogonal to extension, but there are not yet structural data allowing to constrain the dyke opening direction in the N70\%/LDS.

Dyke thickness variations can be also used to deduce the extension direction during dyke emplacement (Baer et al., 1994). Indeed, dyke thickness changes are generally thought to be a function of the orientation of inherited host-fractures with regards to tensile stress (Jolly and Sanderson, 1995). According to Baer and Beyth (1990), the thickness of a given dyke segment (d) that forms an angle $\alpha$ with the optimally oriented segment of maximal thickness (Wmax) is given by the equation :

$$
\mathrm{Wd}=\mathrm{Wmax} * \cos \alpha(2)
$$

Applying the mean dyke thicknesses calculated above for the N70\%/LDS (27 m) and N110\%ODS (17 m) dyke populations indicates $\cos \alpha=0.63$ and $\alpha=50^{\circ}$, i.e. nearly the angle between the $\mathrm{N70}{ }^{\circ} \mathrm{E}$ and $\mathrm{N} 110^{\circ} \mathrm{E}$ dykes swarms in the study area (Fig. 12a).

\section{Discussion and conclusions}

The structural analysis of the N110\%/ODS and N70\%/LDS in NE Botswana provides new insights in: 1) the internal organisation of giant mafic dyke swarms in general and; 2) the structural framework during the emplacement of Karoo magma in northern part of the Karoo LIP. The most important results of this study come from the Shashe section that intersects at high angle the densest dyke zone of the N110\%/ODS. 423 dykes recorded from ground magnetics allow the quantification of the dyke population, whereas the crystalline country-rocks structural features unable us to constrain the role of basement fabrics on the emplacement of Karoo dykes.

The mean thickness for the N110\%/ODS dykes across basement rocks is $\sim 18 \mathrm{~m}$, i.e. it is much greater than 5 to $10 \mathrm{~m}$ considered as common dyke thickness values for giant dyke swarms (Ernst et al., 1995). Field observations along continuously exposed sections demonstrate that the low frequency of narrow dykes (thickness $<5.0 \mathrm{~m}$ ) is a real feature, instead of being due to a biased sampling as could have been envisaged from the $\sim 10 \mathrm{~m}$ interval of ground magnetic records (Tshoso et al., 2004). For reasons that remain to be understood, the asymmetrical distribution of Karoo dyke width data (with a maximum peak at $18 \mathrm{~m}$ ) decreases exponentially to $60 \mathrm{~m}$, and does not conform to the linear scaling relationships usually recorded by dyke/fracture networks (e.g. Walsh and Watterson, 1988; Pickering et al., 1995, and references therein).

The mean thickness of Karoo dyke ranges from $1.3 \mathrm{~m}\left(\mathrm{~N} 110^{\circ} \mathrm{E}\right.$ dykes in sediments of the Tuli basin), to $\sim 18 \mathrm{~m}\left(\mathrm{~N} 110^{\circ} \mathrm{E}\right.$ dykes in basement rocks) and $27 \mathrm{~m}$ (N70 ${ }^{\circ} \mathrm{E}$ dykes in basement, Tsetsebjwe area). The upward narrowing of $\mathrm{N} 110^{\circ} \mathrm{E}$ dykes from basement up to overlying PermoTriassic sedimentary units is a feature known in several dyke swarms in the world and assigned to a decrease of magma pressure at higher structural levels (Ernst et al., 2001). However, dyke width variations might also reflect changes in the extension mechanisms. Comparisons with classical crustal profiles of extensional regions (Pollard et al., 1983; Helgason and Zentilli, 1985; Gudmundsson 1990a) show that crustal dilatation is accomplished through either normal faulting and tilting in the uppermost part of the crust, and dyke intrusion at deeper levels (Fig. 13). 
According to this model, normal faults might have developed during Karoo dyke injection in the uppermost part of the deformational system, as recorded in the Tuli basin (shallow structural level) and they likely have been removed by erosion in the Shashe area where deeply-eroded basement is exposed (deeper structural level). Although normal fault structures spatially associated to Karoo dykes occur in the Tuli down-faulted basin, they clearly post-date mafic dykes (see Fig. 4c). At the present-day erosion level, dykes are thus the primary strain mode in the N110\%/ODS, and the $12 \%$ crustal dilatation calculated along the $52 \mathrm{~km}$-long projected Shashe section is thus exclusively accommodated by Karoo dyke injection.

Concomitant to the vertical change of dyke thickness, dyke shape variations suggest also change in host-rock failure regime. The coexistence of segmented dykes along the Shashe section indicates brittle failure of crystalline basement rocks, whereas the smoother trajectory of dykes intruding the sedimentary series in the Tuli basin likely marks magma injection in a more plastic medium.

The apparent change of Karoo dyke widths from $17 \mathrm{~m}$ in the N110\%ODS to $27 \mathrm{~m}$ in the N70\%/LDS possibly relates either to regional principal stresses at the time of dyke emplacement, or to the pressure and volume of the intruding magma. Given the available data, the simplest interpretation is that the angular relations between the dyke swarm trends and the regional extension controles the widening of the $\mathrm{N} 70^{\circ}$-trending Karoo dykes. Under a $\sim \mathrm{N} 160^{\circ} \mathrm{E}$ extension, (i.e. the direction of dyke opening in the ODS swarm), the $\mathrm{N} 110^{\circ}$ dykes should have dilated as oblique shear fractures, hence recording a smaller amount of extension. In contrast, Karoo dykes of the N70\%/LDS, lying perpendicular to the regional extension, were favourably oriented for opening as pure tensile fractures with a maximum dilatation.

Structural evidence also demonstrates that the $\mathrm{N} 110^{\circ} \mathrm{E}$ (and to a lesser extent the $\mathrm{N} 70^{\circ} \mathrm{E}$ ) trends of the two giant Karoo dyke swarms in NE Botswana follow preexisting fracture zones that also host a Proterozoic dyke complex in the central part of the N110\%ODS (Shashe transect) (Jourdan et al., 2004). Therefore, the main controlling factor for the constant N110\%ODS orientation over more than 2,000 $\mathrm{km}$ is a major basement inherited trend than being the direction of the regional extension. Indeed, the small amount of extension that prevailed during the main phase of flood basalt extrusion, indicated by: (1) the lack of coeval extensional structures in the Okavango dyke swarm and; (2) the flexural (instead of rifted) geometry of Karoo basins (Catuneanu et al., 1998), was not high enough to trigger the emplacement of such a linear giant dyke swarm.

Karoo dyke emplacement mechanisms in the N110\%ODS (Fig. 15b) constrained by the analysis of the anisotropy of magnetic susceptibility indicated that there is a transition from predominantly vertical (Tuli basin) to horizontal (Shashe area) magma flow with increasing distance from the Nuanetsi focal point to the east (Tshoso, 2003). The model of lateral flow of magma is also supported by aeromagnetic data, as shown on figure 14 by the gradual westwards narrowing of the high density dyke zone from $60 \mathrm{~km}$ in the Francistown area to 53 and $45 \mathrm{~km}$ in the Maun and Ngami areas, respectively. Assuming that some of the dyke parameters measured in the Shashe reference section remain constant along-strike, e.g. the ratio of Proterozoic/Karoo dykes $(\sim 1 / 6)$ and the average Karoo dyke thickness $(18 \mathrm{~m})$, estimates of dyke-driven extension can be attempted along seriated structural cross-sections. Extension values decrease abruptly westwards (Table 4) from $7295 \mathrm{~m}$ (12.2 \%) along the Shashe section to $1384 \mathrm{~m}$ (2.6 \%) along the Maun section (400 km to the W) and $1160 \mathrm{~m}$ along the Ngami section (200 km further W) Such a change in the distribution of dykes in the N110\%ODS, coupled with the apparent lack of magma chambers west of the Shashe area, suggest that Karoo mafic dykes propagated laterally westwards, away from the Nuanetsi 
source region (Fig. 15b), instead of being injected vertically from deep-seated linear magmatic ridges.

Most giant dyke swarms are generally regarded as key evidence for mantle plumes beneath the focal region of radiating dyke networks (Ernst and Buchan,1997). This interpretation is not realistic for Karoo dyke swarms, including the N110\%ODS and N70\%ODS in NE Botswana. Indeed, the Lebombo (NS), Olifants River (N20 ${ }^{\circ}$ ) and Limpopo (N70 ${ }^{\circ}$ ) dyke swarms (Fig. 15b) are also polyphased dyke complexes involving both Karoo and Precambrian dykes (Marsh, 2002; Jourdan et al., 2004). The location of the Karoo plutonic centers at Nuanetsi (Cox, et al., 1965; Eales et al., 1984) was fortitiously localised by coincidence of inherited discontinuities (Fig. 15a), particularly the margins of Archaean cratons (Hutchins and Reeves, 1980). Whatever the origin of the magma in the northern Karoo province, either related to incubation (Anderson, 1987) or plume/flat subduction (Dalziel et al., 2000) processes, the magmas probably rose through the crust along preexisting crustal structures. It is thus realistic to infer that the Nuanetsi central intrusive complex served as vertical conduits for upward-migrating magma that later fed laterally the inherited fault-fracture network forming the Karoo dyke system. The inherited and polyphase origin of the fracture network hosting Karoo dykes in the northern Karoo LIP implies that the final radiating arrangement of Karoo giant dyke swarms does not constitute an unequivocal proof for the Karoo mantle plume. The interpretation of the Karoo triple junction-like dyke pattern as the result of radial stress above a plume head, in agreement with the theoretical model of Fahrig (1987), is thus an oversimplification.

\section{References}

Aldiss, D.T., 1981. Tsetsebjwe 1: 250000 geological sheet, Geological Survey of Botswana.

Aldiss, D.T., 1986. Shashe 1: 250000 geological sheet, Geological Survey of Botswana.

Anderson, D.L., 1987. Global mapping of the uppermantle by surface wave tomography, composition, structure and dynamics of the lithosphere asthenosphere system. In: Fuchs, K., Froidevaux, C. (Eds.), Geodynamic series, American Geophysical Union, Washington DC, 16, 327.

Anderson, T.D., Diehl, J.F., 1982. Magnetic investigations of the Baraga country diabase, Michigan. Abstract, Proceedings, 28th Annual Institute on Lake Superior Geology, International Falls, Minnesota, USA, p. 3.

Baer, G., Beyth, M., 1990. A mechanism of dyke segmentation in fractured host rock. In: Parker, A.J., Rickwood, P.C., Tucker, D.H., (Eds.), Mafic Dykes and Emplacement Mechanims, Balkema Rotterdam, pp. 3-11.

Baer, G., Beyth, M., Reches, Z., 1994. Dikes emplaced into fractured basement, Timna Igneous Complex, Israel. Journal of Geophysical Research 99, 24039-24050.

Brewer, T.S., Hergt, J.M., Hawkesworth, C.J., Rex, D., Storey, B.C., 1992. Coats Land dolerites and the generation of Antarctic continental flood basalts, In: Storey, B.C., Alabaster, T., Pankhurst, R.J. (Eds.), Magmatism and the Causes of Continental Break-up. Geological Society of London, Special Publication 68, pp. 185-208.

Burke, K., Dewey, J.F., 1972. Plume generated triple junctions. Key indicators in applying plate tectonics to old rocks. Journal of Geology 81, 403-433. 
Bussel, M.A., 1989. A simple method for the determination of the dilatation direction of intrusive sheets. Journal of Structural Geology 11, 679-687.

Callot, J.P.,Grigné, C., Geoffroy, L. Brun, J.P., 2001. Development of volcanic passive margins: Two-dimensional laboratory models. Tectonics 23, 148-159.

Campbell, I.H., Griffiths, R.W., 1990. Implications of mantle plume structure for the evolution of flood basalts. Earth and Planetary Science Letters 99, 79-93.

Catuneanu, O., Hancox, P.J., Rubidge, B.S., 1998. Reciprocal flexural behaviour and contrasting stratigraphies: a new basin development model for the Karoo retroarc foreland system, South Africa. Basin Research 10, 417-439.

Chandler, V.W., 1986. Interpretation of Precambrian geology in Minnesota using low-altitude, highresolution aeromagnetic data. In: Hinze, W.J. (Eds.), The utility of regional gravimetry and magnetic anomaly maps. Society of Exploration Geophysicists, Tusla, USA, 375-391.

Clark, G.C., Machacha, T.P., 1976. Baines Drift, 1: 250000 geological sheet, Geological Survey of Botswana.

Cox, K.G., Jonhson, R.L., Monkman, L.J., Stillman, C.J., Vail, J.R., Wood, D.N., 1965. The geology of the Nuanetsi igneous province, Philosophical Transactions Royal Society of London A257, 71-218.

Cox, K.G., 1992. Karoo igneous activity, and the early stages of the break-up of Gondwanaland. In: Storey, B.C., Alabaster, T., Pankhurst, R.J. (Eds.), Magmatism and the Causes of Continental Break-up. Geological Society of London, Special Publication 68, pp. 137-148.

Dalziel, I.W., Lawver, L.A., Murphy, J.B., 2000. Plumes, orogenesis, and supercontinental fragmentation. Earth and Planetary Science Letters 178, 1-11.

Delaney, P.T., Pollard, D.D., Zioney J.I. McKee, E.H., 1986. Field relations between dikes and joints: emplacement processes and paleostress analysis. Journal of Geophysical Research 91, 4920-4938.

Eales H.V., Marsh, J.S., Cox, K.G., 1984. The Karoo igneous province : an introduction. In: Erlank A.J. (Ed.), Petrogenesis of the volcanic rocks of the Karoo province, Geological Society of South Africa Special Publication 13, 1-26.

Elburg, M., Goldberg, A., 2000. Age and geochemistry of Karoo dykes from northeast Botswana. Journal of African Earth Sciences 31, 539-554.

Elliott, D.H., 1992. Jurassic magmatism and tectonism associated with Gondwanaland break-up: an Antarctic perspective. In: Storey, B.C., Alabaster, T., Pankhurst, R.J. (Eds.), Magmatism and the Causes of Continental Break-up. Geological Society of London, Special Publication 68, pp. 165-184.

Ernst, R.E., Buchan, K.L., Palmer, H.C., 1995. Giant dyke swarms: Characteristics, distribution and geotectonic implications. In: Baer, G., Heimann A. (Eds.), Physics and Chemistry of Dykes, Balkema, Rotterdam, pp. 3-21.

Ernst, R.E., Buchan, K.L., 1997. Giant radiating dyke swarms: Their use in identifying preMesozoic large igneous provinces and mantle plumes. In: Mahoney, J.J., Coffin, M.F. (Eds), 
Large igneous provinces: continental, oceanic and planetary flood volcanism. AGU Geophysical Monograph 100, 297-333.

Ernst, R.E., Grosfils, E.B., Mège, D., 2001. Giant dyke swarms: Earth, Venus and Mars. Annual Review Earth Planetary Science 29, 489-534.

Fahrig, W.F., 1987. The tectonic settings of continental mafic dyke swarms. In: Halls, H.C., Fahrig, W.F. (Eds.), Mafic dyke swarms, Geological Association Canada, Special paper 34, 331-348.

Geoffroy, L., 2001. The structure of volcanic margins: some problematics from the North Atlantic/Labrador-Baffin system. Marine and Petroleum Geology 18, 463-469.

Gudmundsson, A., 1990a. Emplacement of dikes, sills and crustal magma chambers at divergent plate boundaries. Tectonophysics 176, 257-275.

Gudmundsson, A., 1990b. Dyke emplacement at divergent plate boundaries. In: Parker, A.J., Rickwood, P.C., Tucker, D.H. (Eds.), Mafic Dykes and Emplacement Mechanims. Balkema Rotterdam, 47-62.

Head, J.W., Wilson, L., Smith, D.K., 1996. Mid-ocean eruptive vent morphology and substructure: evidence for dike widths, eruption rates, and evolution of eruptions and axial volcanic ridges. Journal of Geophysical Research 101, 28265-28280.

Helgason, J., Zentilli, M., 1985. Field characteristics of laterally emplaced dikes: anatomy of an exhumed Miocene dike swarm in Reydarfjordur, eastern Iceland. Tectonophysics 115, 247-274.

Hoek, J.D., 1991. A classification of dyke-fracture geometry with examples from Precambrian dyke swarms in the Vesfold Hills, Antarctica. Geologische Rundschau 80, 233-248.

Hutchins, D.G., Reeves, C.V., 1980. Regional geophysical exploration of the Kalahari in Botswana. Tectonophysics 69, 201-220.

Jolly, R.H., Sanderson, D.J., 1995. Variation in the form and distribution of dykes in the Mull swarm, Scotland. Journal of Structural Geology 17, 1543-1557.

Jones, D.L., Duncan, R.A., Briden, J.C., Randall, D.E., MacNiocaill, C., 2001. Age of the Batoka basalts, northern Zimbabwe, and the duration of Karoo Large Igneous Province magmatism. Geochemistry, Geophysics, Geosystems 2, 1-15.

Jourdan, F., Féraud, G., Bertrand, H., Kampunzu, A.B., Tshoso, G., Le Gall, B., Tiercelin, J.J., Capiez, P. 2004. The Karoo triple junction questioned: evidence from ${ }^{40} \mathrm{Ar} /{ }^{39} \mathrm{Ar}$ Jurassic and Proterozoïc ages and geochemistry of the Okavango giant dyke swarm (Botswana). Earth and Planetary Science Letters 222, 989-1006.

Karson, J.A., Klein, E.M., Hurst, S.D., 1999. Internal structure of uppermost fast-spread oceanic crust of the East Pacific Rise exposed at the Hess Deep Rift: Results from Alvin, Argo II, and DSI 120 investigations. (Abstract) EOS Transactions AGU F983-F984.

Le Gall, B., Thsoso, G., Jourdan, F., Féraud, G., Bertrand, H., Tiercelin, J.J., Kampunzu, A.B., Modisi, M., Dyment, J., Maia, M. 2002. ${ }^{40} \mathrm{Ar}-{ }^{39} \mathrm{Ar}$ geochronology and structural data from the giant Okavango and related mafic dyke swarms, Karoo igneous province, N Botswana. Earth and Planetary Science Letters 202, 595-606.

Lippard, S.J., Shelton, A.W., Gass, I. (Eds.), 1986. The ophiolite of northern Oman. Oxford, Blackwell, 178 p. 
Marsh, J., 2002. Discussion « The geophysical mapping of Mesozoic dyke swarms in southern Africa and their origin in the disruption of Gondwana ». Journal African Earth Sciences 35, 525-527.

McCourt, S., Armstrong, R.A., 1998. SHRIMP U-Pb zircon geochronology of granites from the Central Zone, Limpopo belt, southern Africa: implications for the age of the Limpopo Orogeny. South Africa Geological Society 101, 329-338.

Motamedi, S., 1984. The Keweenawan lavas in the City of Duluth. Unpublished M.S. Thesis, University of Minessota, $140 \mathrm{p}$.

Pickering, G., Bull, L.M., Sanderson, D.J., 1995. Sampling power-law distributions. Tectonophysics 248, 1-20.

Pollard, D.D., Delaney, P.T., Duffield, W.A., Endo, E.T., Okamura, A.T., 1983. Surface deformation in volcanic rift zones. Tectonophysics 94, 541-584.

Reeves, C.V., 2000. The geophysical mapping of Mesozoic dyke swarms in southern Africa and their origin in the disruption of Gondwana. Journal of African Earth Scieces 30, 499-513.

Storey, B.C., Alabaster, T., Hole, M.J., Pankhurst, R.J., Weaver, H.E., 1992. Role of subductionplate boundary forces during the initial stages of Gondwana breakup: evidence from the protoPacific margin of Antartica. In: Storey, B.C., Alabaster, T., Pankhurst, R.J. (Eds.), Magmatism and the Causes of Continental Break-up. Geological Society of London, Special Publication 68, pp. 149-163.

Tshoso, G., 2003. Structure, chronologie et mode de mise en place du système de dykes géants de l'Okavango, Nord Botswana. Une approche pluridisciplinaire. Ph.D. Thesis, Brest University, $186 \mathrm{p}$.

Tshoso, G., Dyment, J., Atekwana, E., Kampunzu, A.B., Tiercelin, J.J., Modisi, M.P., Ngwisanyi, T.H., Le Gall, B., 2004. Emplacement of the Okavango dyke Swarm (Botswana): a multiple approach using magnetic anomalies at three different scales. Journal Geophysical Research, submitted.

Walker, G.P., 1987. The dike complex of Koolau volcano, Oahu: internal structure of a Hawaiian rift zone. U.S. Geological Survey, Professional Paper 1350, 961-993.

Walker, G.P.,1993. Re-evaluation of inclined intrusive sheets and dykes in the Cuillins volcano, Isle of Skye. In: Prichard, H.M., Alabaster, T., Harris, N.B., Neary, C.R. (Eds.), Magmatic processes and Plate Tectonics. Geological Society of London, Special Publication 76, pp. 489497.

Walsh, J.J., Watterson, J., 1988. Analysis of the relationship between the displacements and dimensions of faults. Journal of Structural Geology 10, 239-247.

White, R.S., 1992. Magmatism during and after continental break-up. In: Storey, B.C., Alabaster, T., Pankhurst, R.J. (Eds.), Magmatism and the Causes of Continental Break-up. Geological Society of London, Special Publication 68, pp. 1-16.

White, R.S., McKenzie, D.P., 1989. Magmatism at rift zones: the generation of volcanic continental margins and flood basalts. Journal of Geophysical Research 94, 7685-7729.

Wilson, J.F., 1990. A craton and its cracks: some of the behaviour of the Zimbabwe block from the Late Archaean to the Mesozoic in response to horizontal movements, and the significance of some of its mafic dyke fracture patterns. Journal of African Earth Sciences 10, 483-501. 


\section{FIGURE CAPTIONS}

Fig. 1(a) Distribution of continental flood basalt and related intrusive rocks of the KarooFerrar/Antarctica large igneous province in a pre-drift Gondwana reconstruction. 1. Exposed complexes; 2. Extrapolated magmatic rocks; 3. Inferred magmatic units beneath ice cover in western Antarctica. 1(b) Karoo tectono-magmatic framework of southern Africa. The inset shows the studied area in NE Botswana. 1. Magmatic complexes with 1a. Flood basalt; 1b. Dykes and sills; 1c. Eruptive centres; 2. Sedimentary basins. L., Lesotho; LDS., Lebombo dyke swarm; MTZ., Mozambique thinned zone; N., Nuanetsi; ODS., Okavango dyke swarm; ORDS., Olifants River dyke swarm; SBDS., South Botswana dyke swarm; SLDS., Sabi-Limpopo dyke swarm; SLeDS., South Lesotho dyke swarm; SMDS., South Malawi dyke swarm; ZF., Zoetfontain fault.

Fig. 2. The studied areas in the geological context of NE Botswana. (a) Simplified geological map of NE Botswana showing the $\mathrm{N} 110^{\circ}$ (Okavango) and N70 (Sabi-Limpopo) dyke swarms. The Shashe reference section (and its projected trace in dashed line) and the Tsetsebjwe (Ts) and Tuli (THG) sectors are shown. 1a. Regional envelop of the highest dyke density zones in the $\mathrm{N} 110^{\circ}$ and $\mathrm{N70}^{\circ}$ swarms (derived from aeromagnetic data); 1b. Envelop of the swarm observed along the Shashe section. 2. Flood basalt; 3. Karoo basins; 4. Precambrian basement with; 4a. dominantlygneissic rocks, 4b. granites; 5. Major extensional faults. Fr., Francistown quarry; G., Gulubane; MF., Magogaphate fault; ODS., Okavango dyke swarm; P., Phoenix quarry; SD., Shashe Dam; T., Tonotha; TS., Tsetsebjwe section. (b) Map-view of the Shashe reference section. The dyke pattern is too intense to be shown in its entirety. It is drawn from published geological maps of the Geological Survey of Botswana (Aldiss, 1986).

Fig. 3. The Shashe reference section (52 km-long) projected perpendicularly to the $\mathrm{N} 110^{\circ}$ trend of the ODS. (a) Host-rocks; (b) Conditions of exposures; (c) Frequency distribution of dykes in the field. I, II, III, and IV are transects discussed in the text. ' $\mathrm{Y}$ ' is the Karoo dyke population within the total number of dated dykes ' $\mathrm{X}$ '; the corresponding percentage of Karoo dykes is indicated.

Fig. 4. Dip attitude of dykes and faults in the N110\%ODS. (a) Dip distribution of 82 dykes in the Shashe section. 91\% of dykes are vertical. (b) Diagram of fault dip versus striation pitch measured in the Thune section. (c) Structural section along the southern margin of the Tuli half-graben (see location of the Thune section in Figs. 2a, 5a). Note the general tilt of the sedimentary host-rocks and the inclined position of the dykes. (d) Inclined attitude of a $60 \mathrm{~cm}$-wide Karoo dyke intruding shallowly-dipping sedimentary rocks (see location in section 4c). (e) Karoo dyke wall reactivated as a dip-slip normal fault (see location in section 4c). Near-vertical slickensides plunge $80^{\circ}$ to the $\mathrm{S}$.

Fig. 5. 2D-geometry (horizontal view) of Karoo dykes intruding Permo-Triassic sedimentary rocks in the southern margin of the Tuli half-graben (Thune section). (a) Geological map of the Thune river area, modified from Clark and Machacha (1976). (b) Cartographic distribution and shape of a braided system of dykes centered on both sides of a Karoo gabbroic intrusion. (c) Rose diagram showing the restricted range of the dyke/fracture orientation. 
Fig. 6. Form of N110\%ODS dykes cutting across Precambrian metamorphic rocks in the Shashe area. Map-view (a) and strike attitude (b) of Karoo dykes in the Phoenix quarry (see location in Fig. $2 a)$. $\left(b_{1}, b_{2}\right.$ ). Frequency and cumulative length distributions of the dykes versus azimuth. (c) Detailed structural map of the Shashe Dam area (see location in Fig. 2a) showing the segmented shape of most dykes. (d) Relations between the zigzag-shaped dykelet 'c' and adjacent structures in the basement. Black arrows indicate the direction of dyke/fracture opening (discussion in the text). (e) Rose diagram of dyke segment orientations.

Fig. 7. Thickness distribution of dykes in the N110\%ODS. (a) Frequency of dykes measured in the field along the Shashe (projected) section. The four transects (I, II, III, IV) are distinguished as a function of the occurrence of basement and/or Karoo dykes (see text); $x, y$, same meaning as for Fig. 3c. (b, c, d, e). Histograms of width for various dyke populations identified from field observations (left column), and ground magnetics (right column). (b) Total dyke population; (c, d, e) Dyke population of transects I, II, and IV, respectively.

Fig. 8. Distribution of Karoo dyke widths in transects I, II, and IV of the Shashe section. The missing interval (20-42 km) corresponds to the composite segment III where basement and Karoo dykes are not discriminated. Note: (1) the random distribution of dyke thicknesses within each transect and; (2) the northwards increase of thick dykes.

Fig. 9. Frequency and cumulative width of dykes in the projected Shashe section. (a) Distribution of dykes from field observations, (x,y) have the same meaning as in Fig. 3c. Frequency (b) and cumulative width (c) of both Karoo (upper part) and basement (lower part) dykes per $2 \mathrm{~km}$ interval, as deduced from ground magnetic anomaly mapping. X, Y, and Z (and the corresponding \%) are transects discussed in the text.

Fig. 10. Field evidence for dyke-induced brittle deformation in Precambrian granites and gneisses of the N110\%/ODS (Shashe area). (a, b) Vertical section showing a dense fracture/joint network developed in tonalitic basement host-rocks, parallel to the margins of a steep Karoo dyke (1.2 mthick); the fracture zone is $\sim 4$ m-wide away of dyke contacts (Francistown quarry, location in Fig. 2a). Assuming that the offset of the pegmatite vein does not result from displacement along the host fracture prior to dyke emplacement, a significant vertical shear component of dyke opening is thus indicated by this figure. (c) Dyke-parallel fracture network spatially restricted to granite countryrocks adjacent to a $110^{\circ}$ E Karoo dyke (Shashe Dam, location in Fig. 6c).

Fig. 11. Direction of dyke dilatation in the N110\%ODS (Shashe section). (a) Direction of dyke opening (at $\sim \mathrm{N} 160^{\circ} \mathrm{E}$ ) deduced from matching opposite walls in a segmented dyke (location in Fig. 6c). (b) Strike, width and length data from the segmented dyke of Fig. 11a. (c) Field view of the zigzag pattern between segments 7 and 8 of dyke in Fig. 11a. (d) Width/strike diagram of 12 dyke segments drawn on Fig. 11a. (e, f) Dilatation vector deduced from matching, either (e) pairs of steps in $\mathrm{N} 110^{\circ} \mathrm{E}$ dykelets (Chadibe area, location in Fig. 3) or (f) chlorite-filled veins on opposite dyke walls $\left(\mathrm{N} 120^{\circ} \mathrm{E}\right)$ in granitic host-rocks (Shashe Mooke area, location in Fig. 3c). 
Fig. 12. Sketch map-view showing variations of dyke thickness as a function of the angle $(\alpha)$ between the dyke azimuth and the direction of regional extension.

Fig. 13. 3-D diagram summarizing the configuration of extensional structures in the upper crust of a volcanic rift zone (modified from Helgason and Zentilli, 1985). The Okavango dyke swarm in the Shashe basement area might correspond to deeply eroded structural levels (approximate depth of a few kilometers) where Karoo crustal extension was dominantly in the form of dyke injection.

Fig. 14. Aeromagnetic dataset of NE Botswana (from Tshoso, 2003, modified). (a) Lowresolution aeromagnetic map showing: (1) the constant strike $\left(\mathrm{N} 110^{\circ} \mathrm{E}\right)$ of the Okavango dyke swarm over more than 1,500 km and; (2) the progressive narrowing of the N110/ODS towards the west. Rectangles are regions where high-resolution aeromagnetic data are available. F., Francistown (study area), M., Maun, N., Ngami. (b) High-resolution aeromagnetic map of the Ngami area. (c) High-resolution aeromagnetic map of the Maun area. (d) High-resolution aeromagnetic map of the Francistown area. C.Z., N.Z., S.Z., Central, Northern and Southern zones; H.D.D., High dyke density.

Fig. 15. Major Precambrian and Karoo structural features of West Gondwana. (a) Basement boundaries in southern Africa. 1. Palaeozoic belt; 2. Proterozoic belts; 3. Craton; 4. Dyke swarms; 5. Suture lines. GD, Great Dyke; MSZ, Magogaphate shear zone; PT, Pongola rift trend; ODS, Okavango (proto) dyke zone; VT, Venterdorp rift trend. (b) Karoo tectono-magmatic framework of southern Africa at the onset of the Middle Jurassic magmatic activity. Constraints on the direction of extension are limited (mainly from our data on NE Botswana Karoo dykes). LDS, LS, ODS, ORDS, SBDS, SLeDS., Limpopo, Lebombo, Okavango, Olifants River, South Botswana and South Lesotho dyke swarms, respectively; N., Nuanetsi. (c) Pangea break-up stage showing the development of a spreading ridge and two NS transform faults, kinematically compatible with a nearly $\mathrm{N} 160^{\circ} \mathrm{E}$ extension.

Table 1. Dyke dataset acquired in the three areas under study. Note that dyke populations in the Shashe, Tuli and Tsetsebjwe areas are not comparable in number.

Table 2. Mean dyke thickness calculated for different dyke populations in the Shashe section.

Table 3. Compiled dyke width data from continental and oceanic ridge settings.

Table 4. Variations of the width and dyke-induced extension in the high dyke density zone of the N110\%/ODS (from aeromagnetic dataset of Tshoso, 2003, calibrated using the Shashe section). 


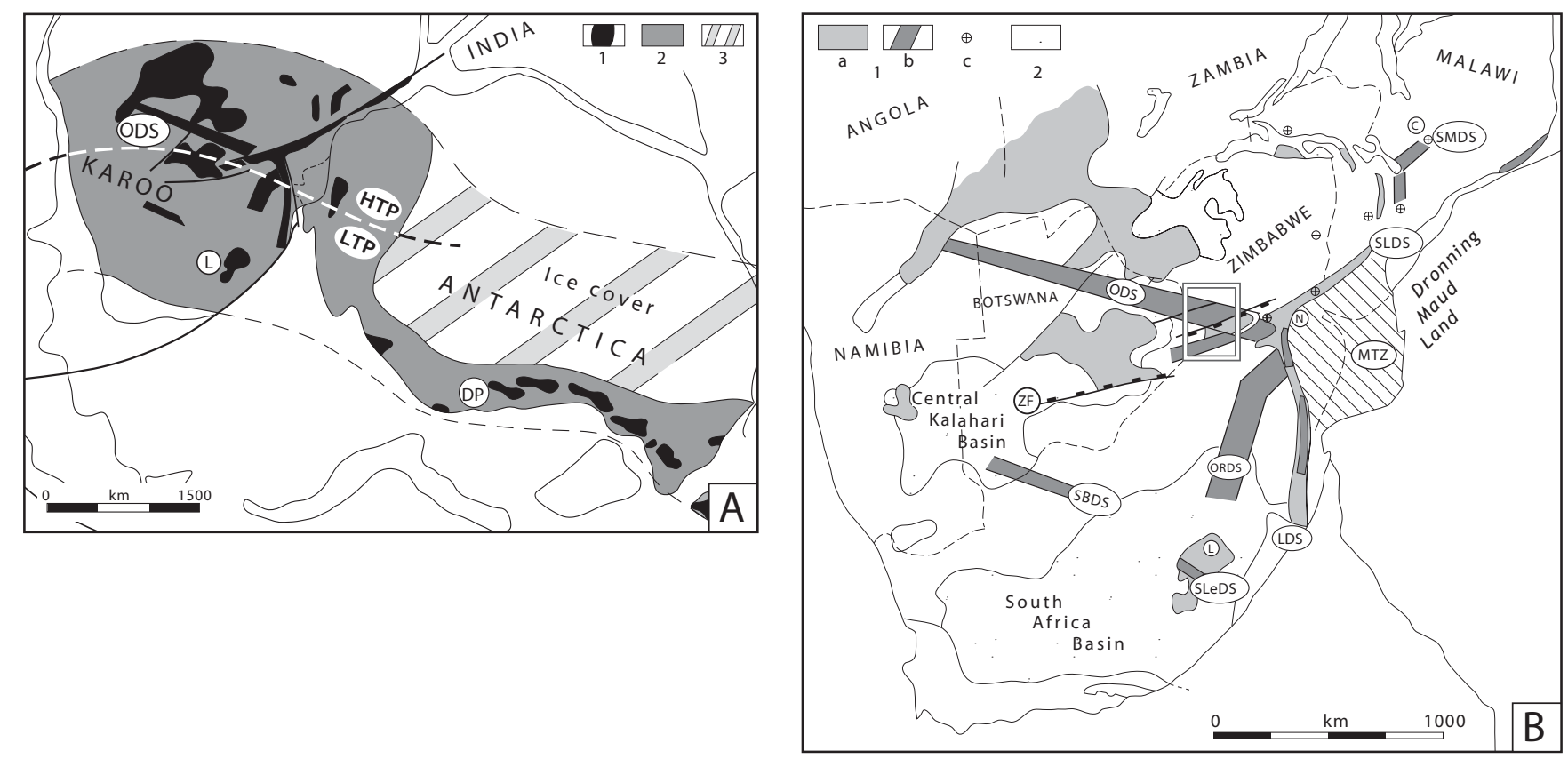

Fig. 1 


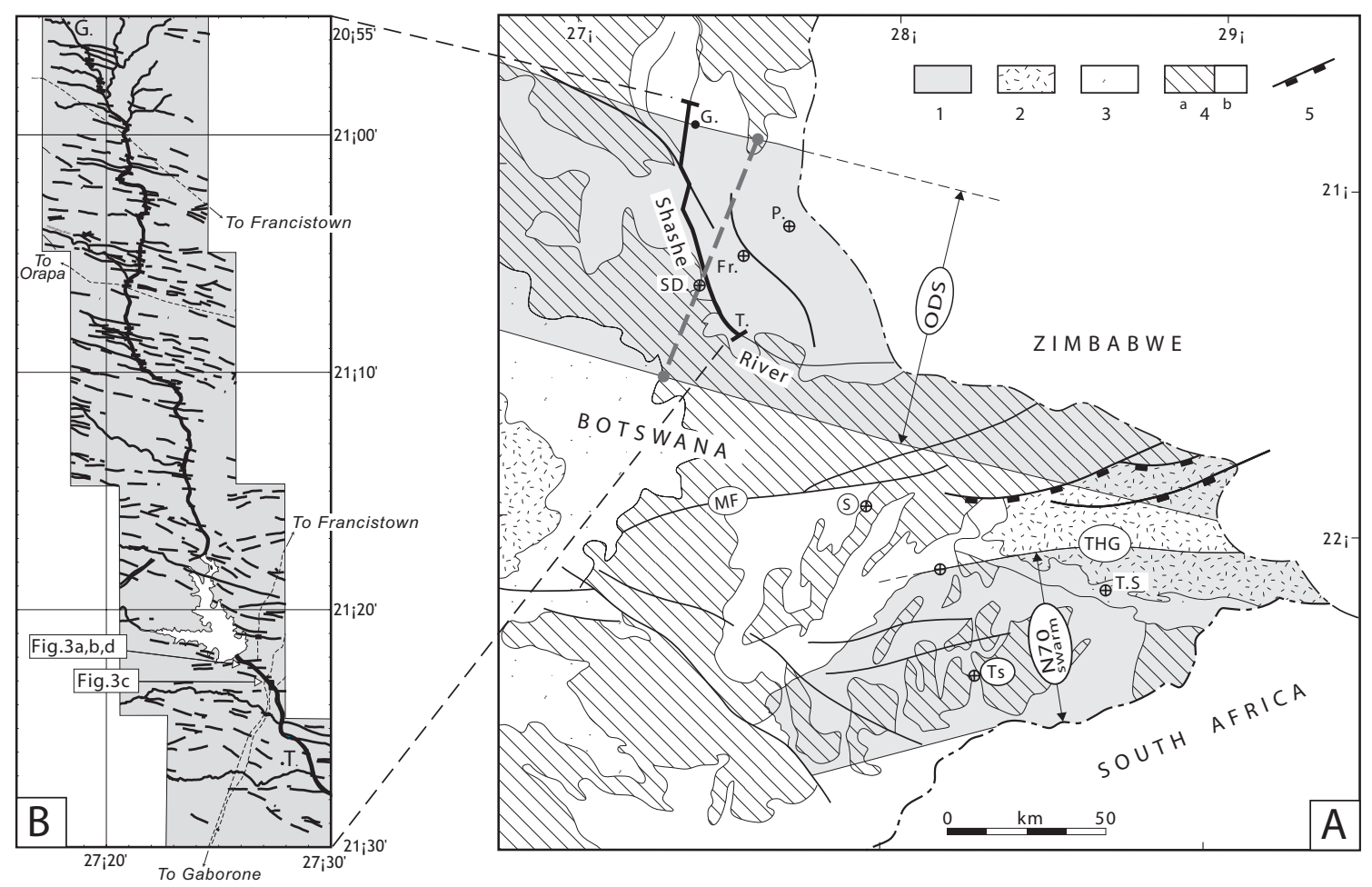

Fig. 2 
A Host-rocks

$+\quad$ Granitoid-gneissic rock

Amphibolites

E Mafic sills

Highly faulted zone
B Outcrop exposures

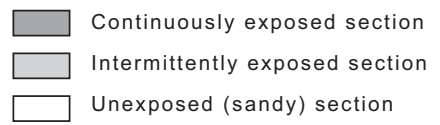

C

|||| Number of dykes (1 to 5)

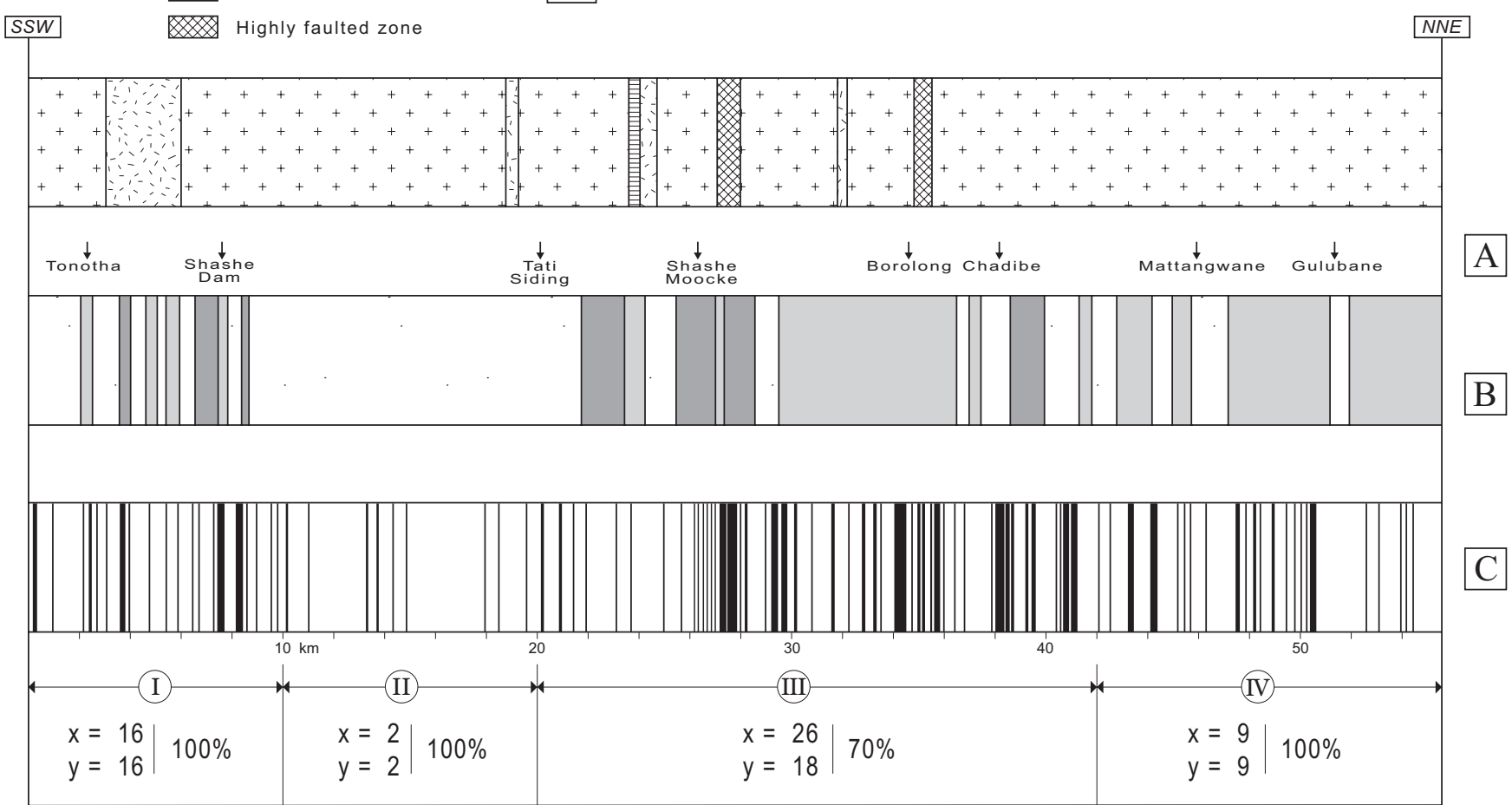

Fig. 3 

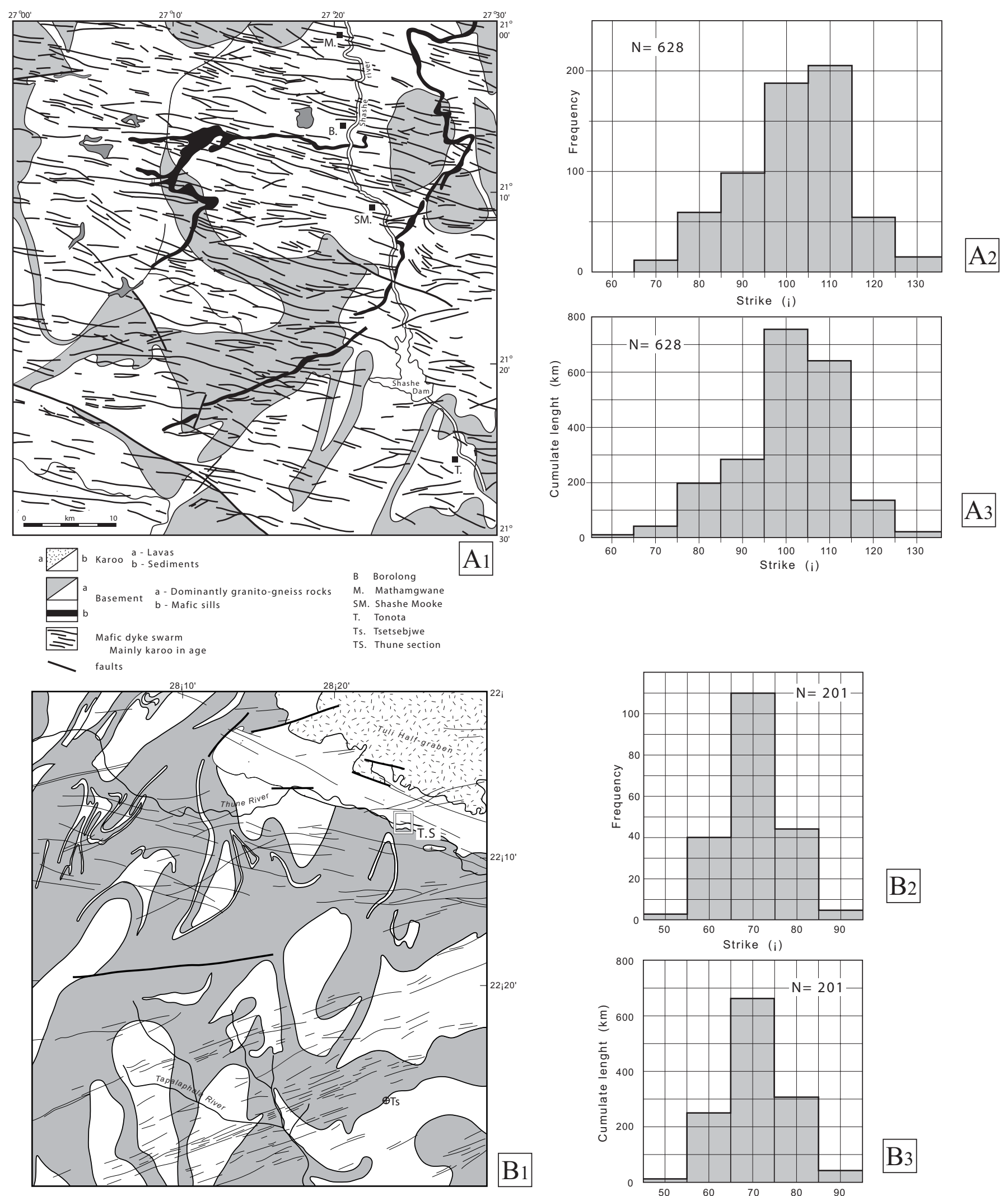

A3
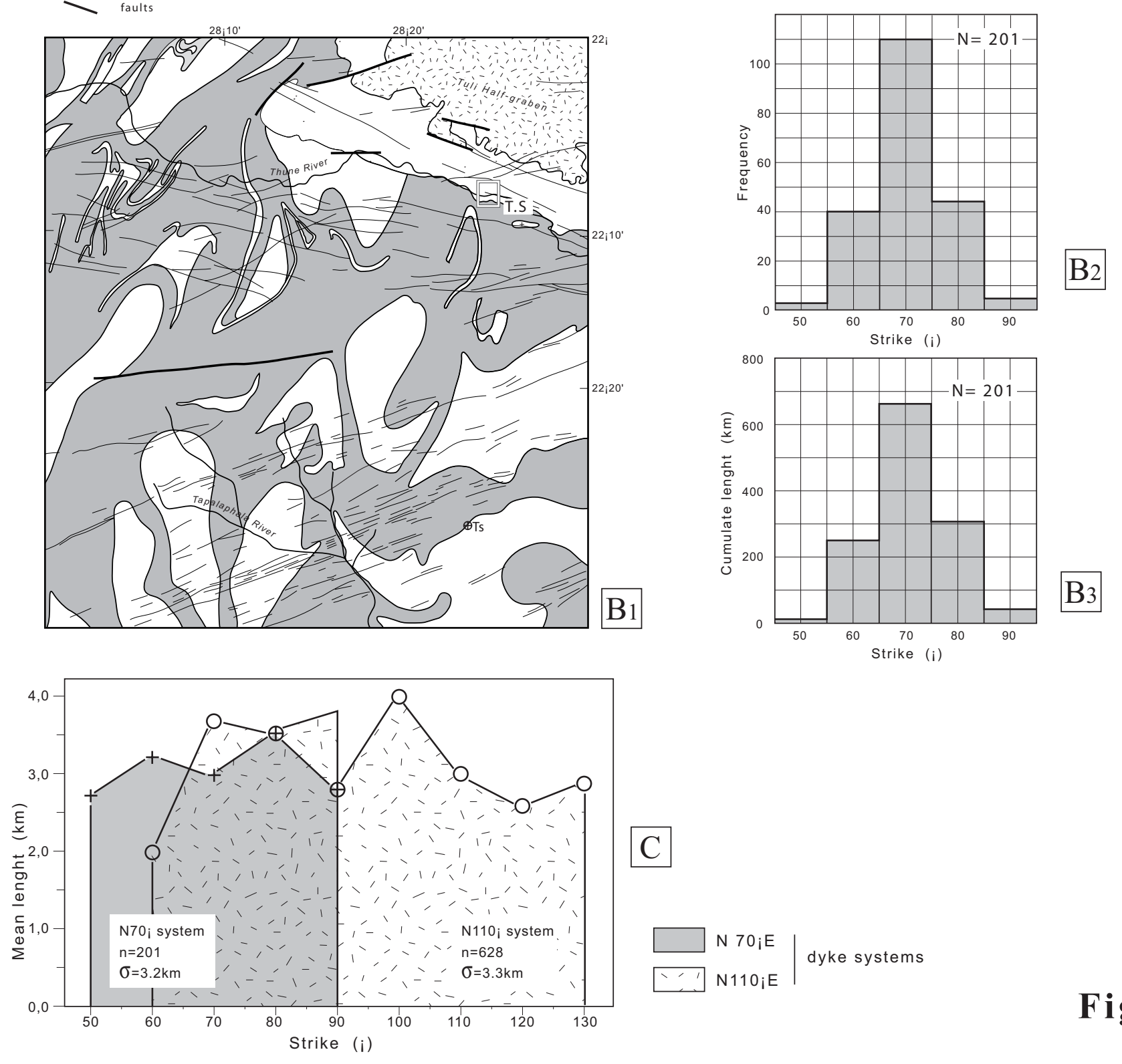

$\mathrm{C}$

\begin{tabular}{l|l}
$\mathrm{N} 70 \mathrm{iE}$ & dyke systems
\end{tabular}

Fig. 4 


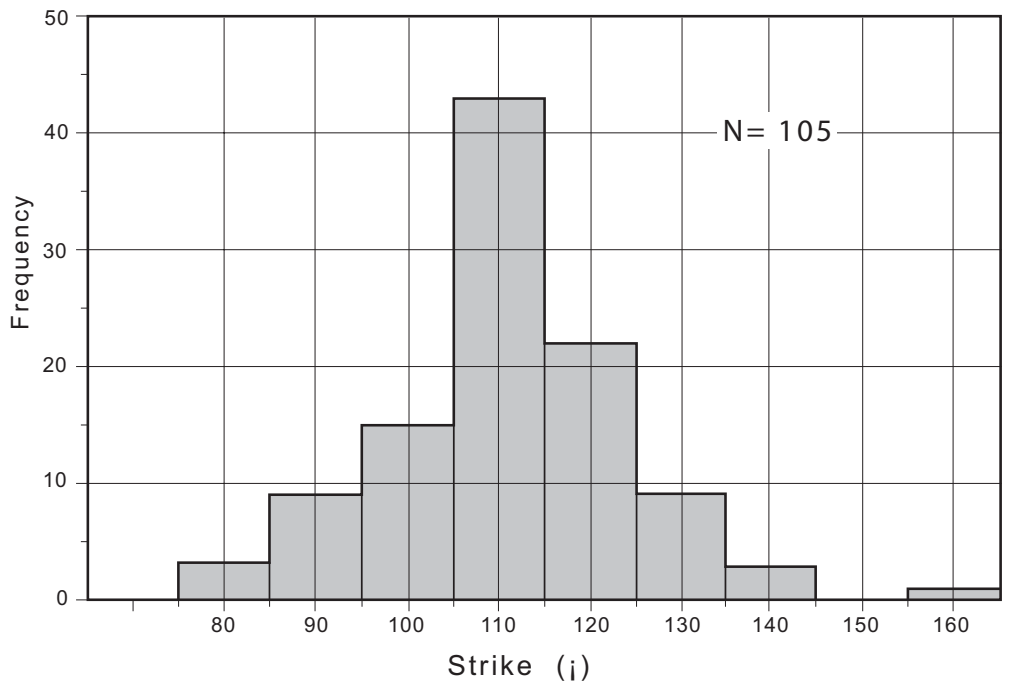

Fig. 5 


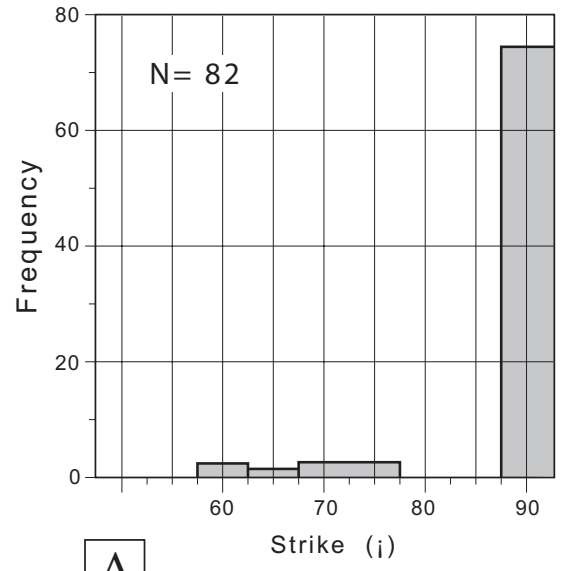

$\mathrm{A}$
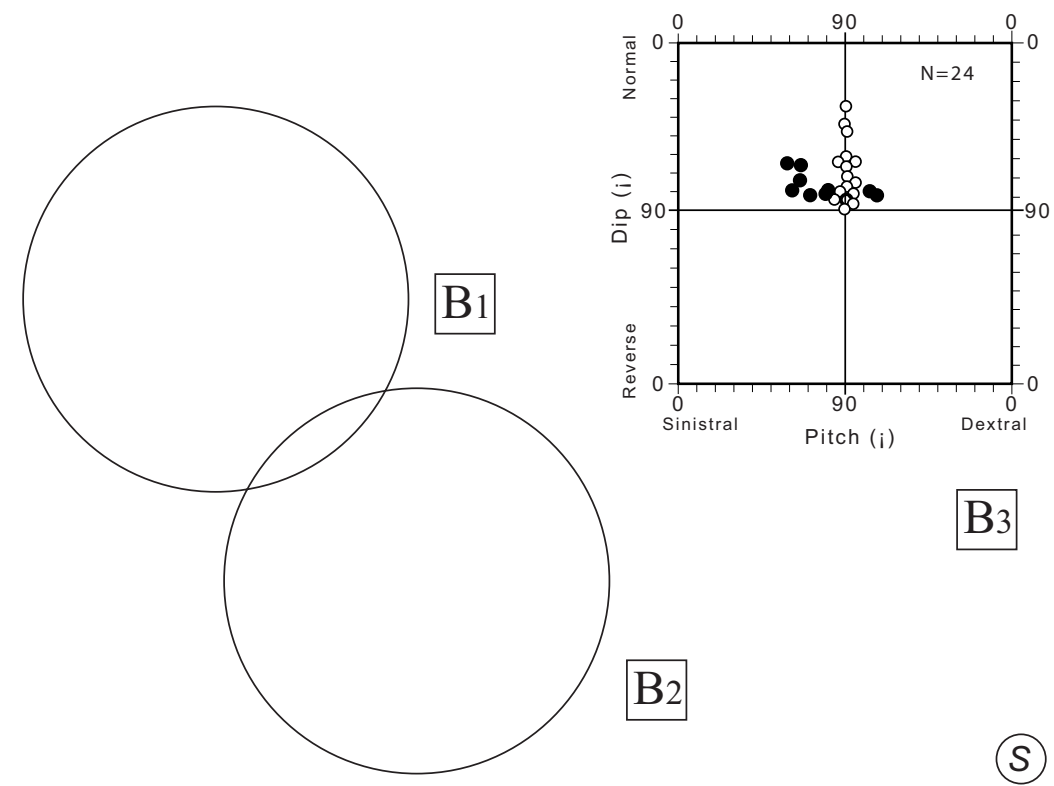

$\mathrm{B}_{2}$

(N)

Thune
River
Blluvium
Babalt
Gabbro
Permo-Triassic sediments

(S)
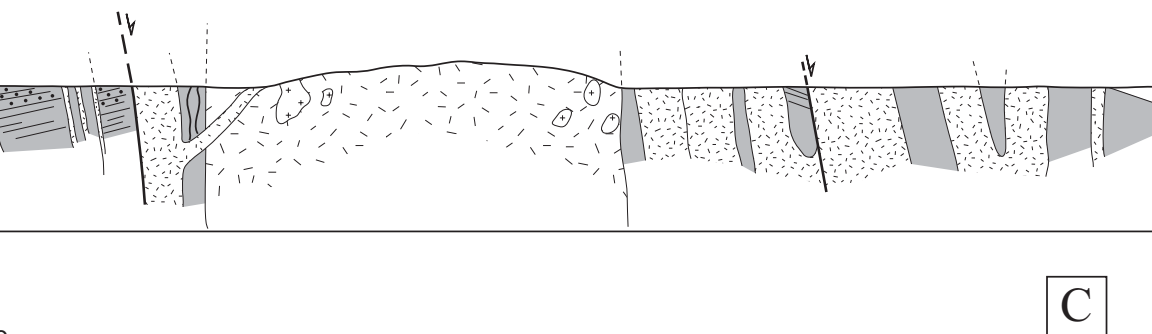

D

Fig. 6 

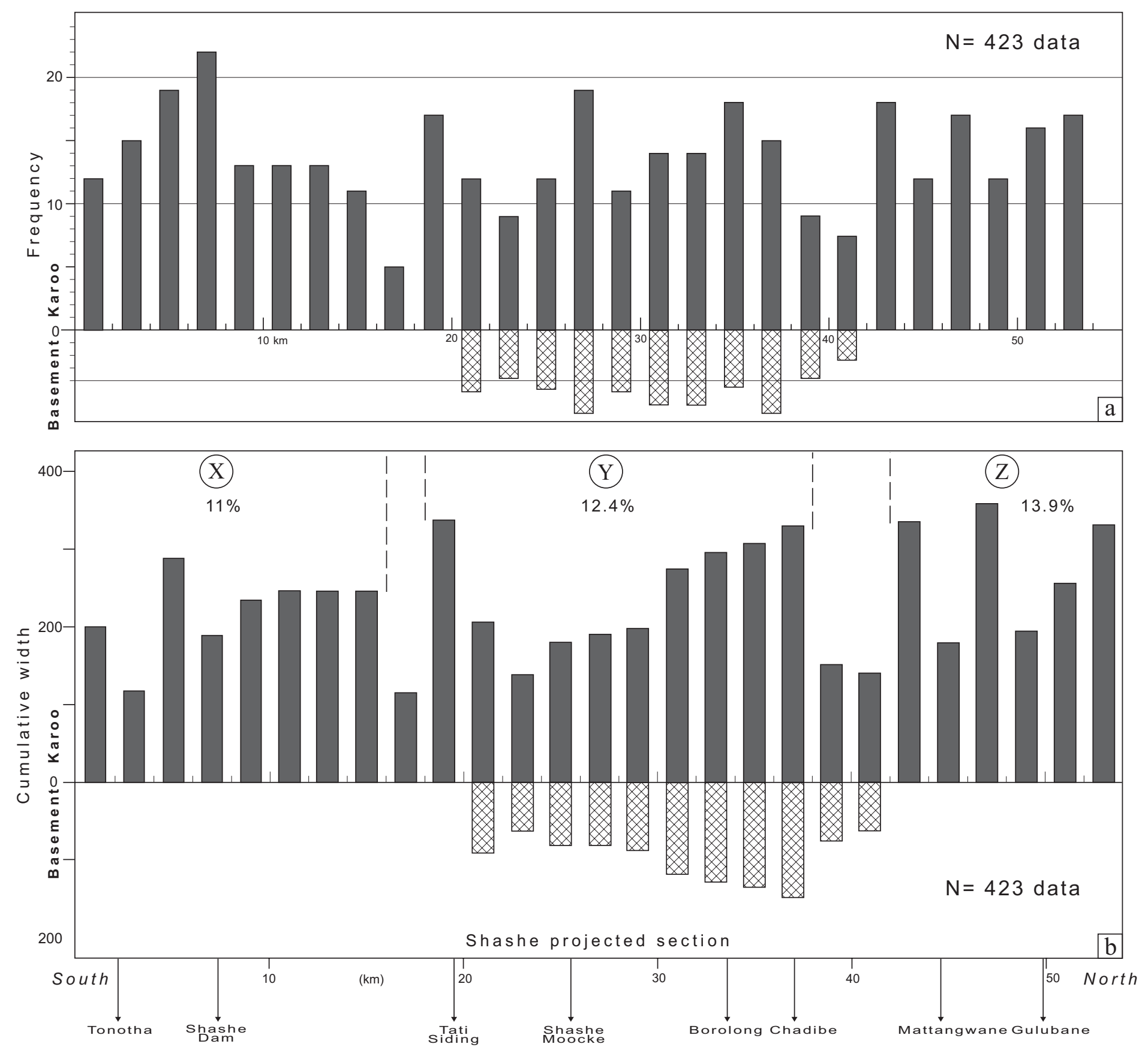


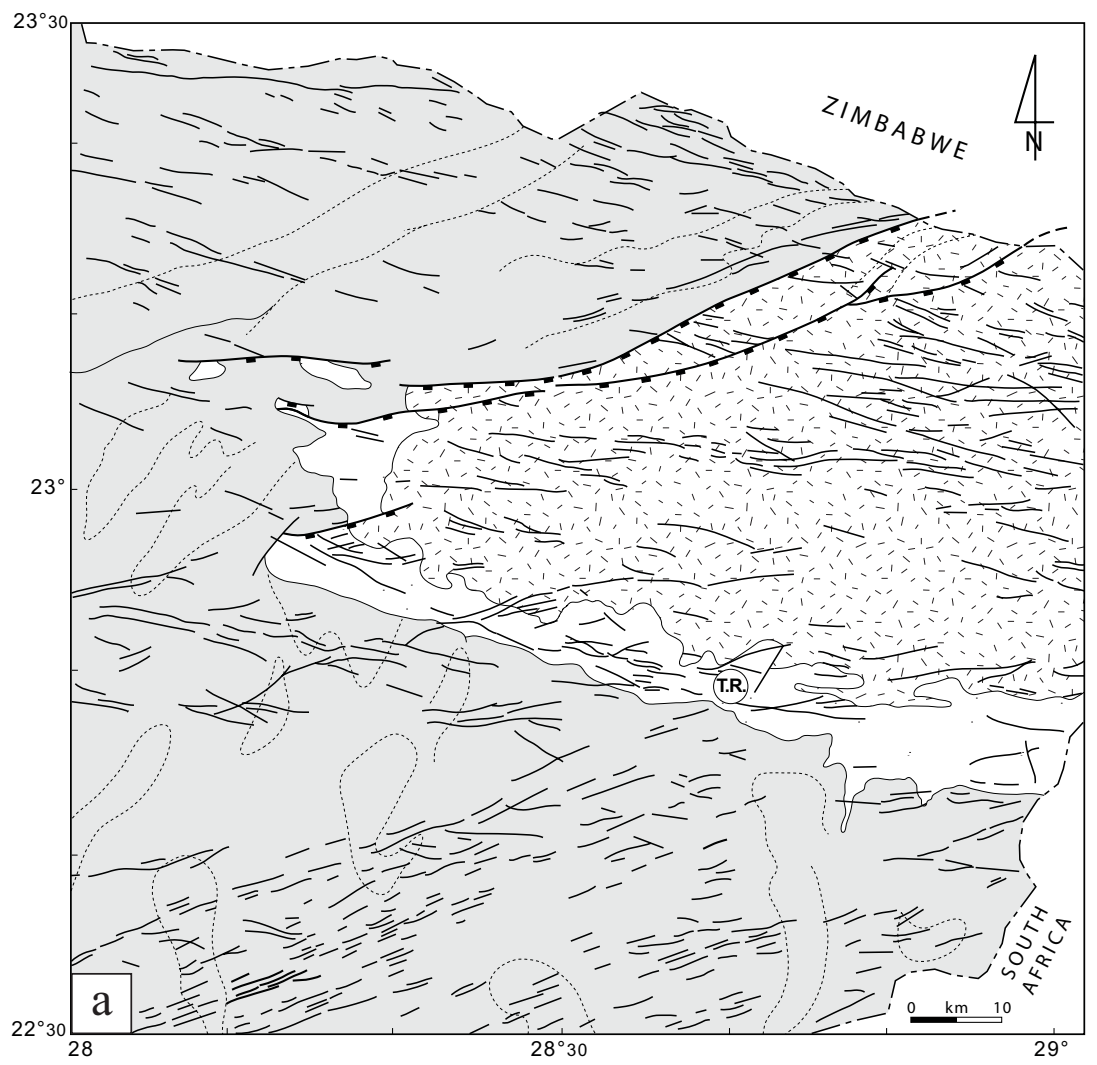

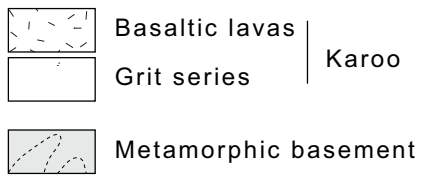

Normal fault

Mafic dykes

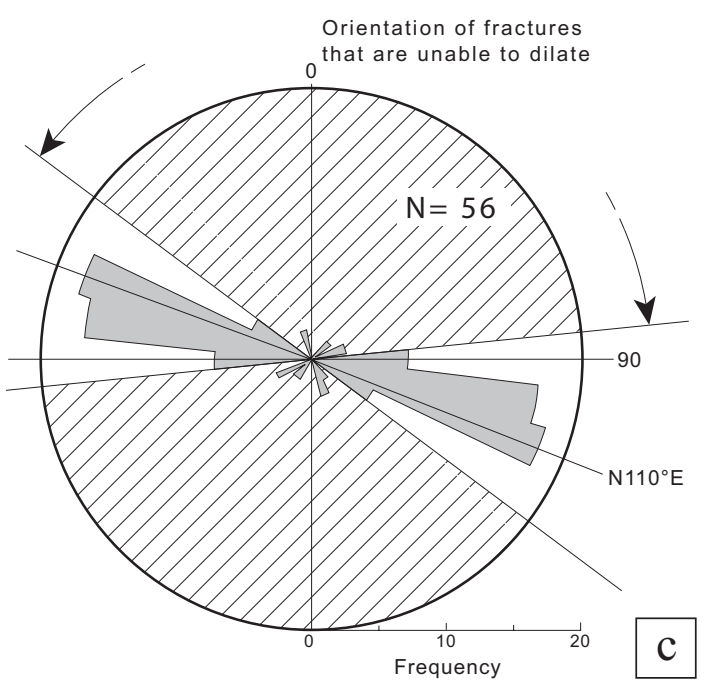

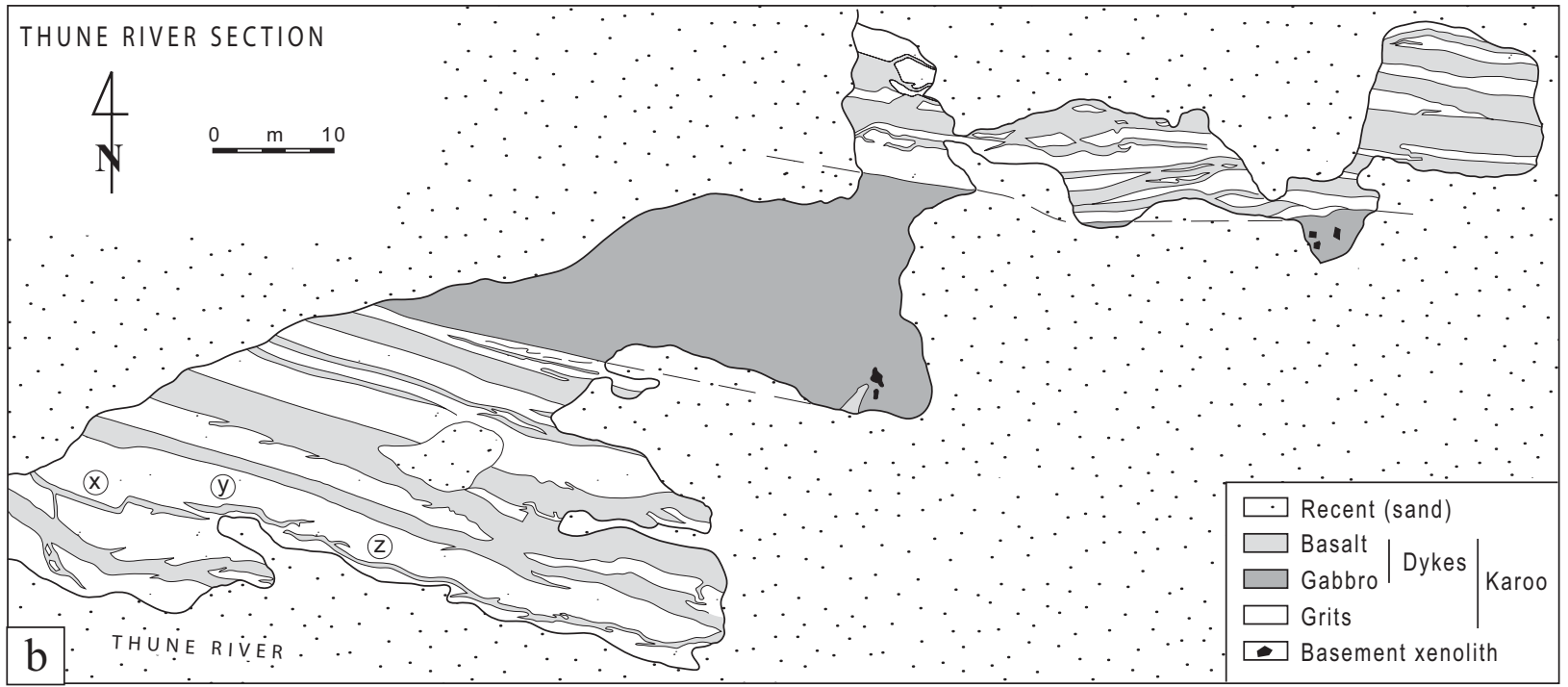



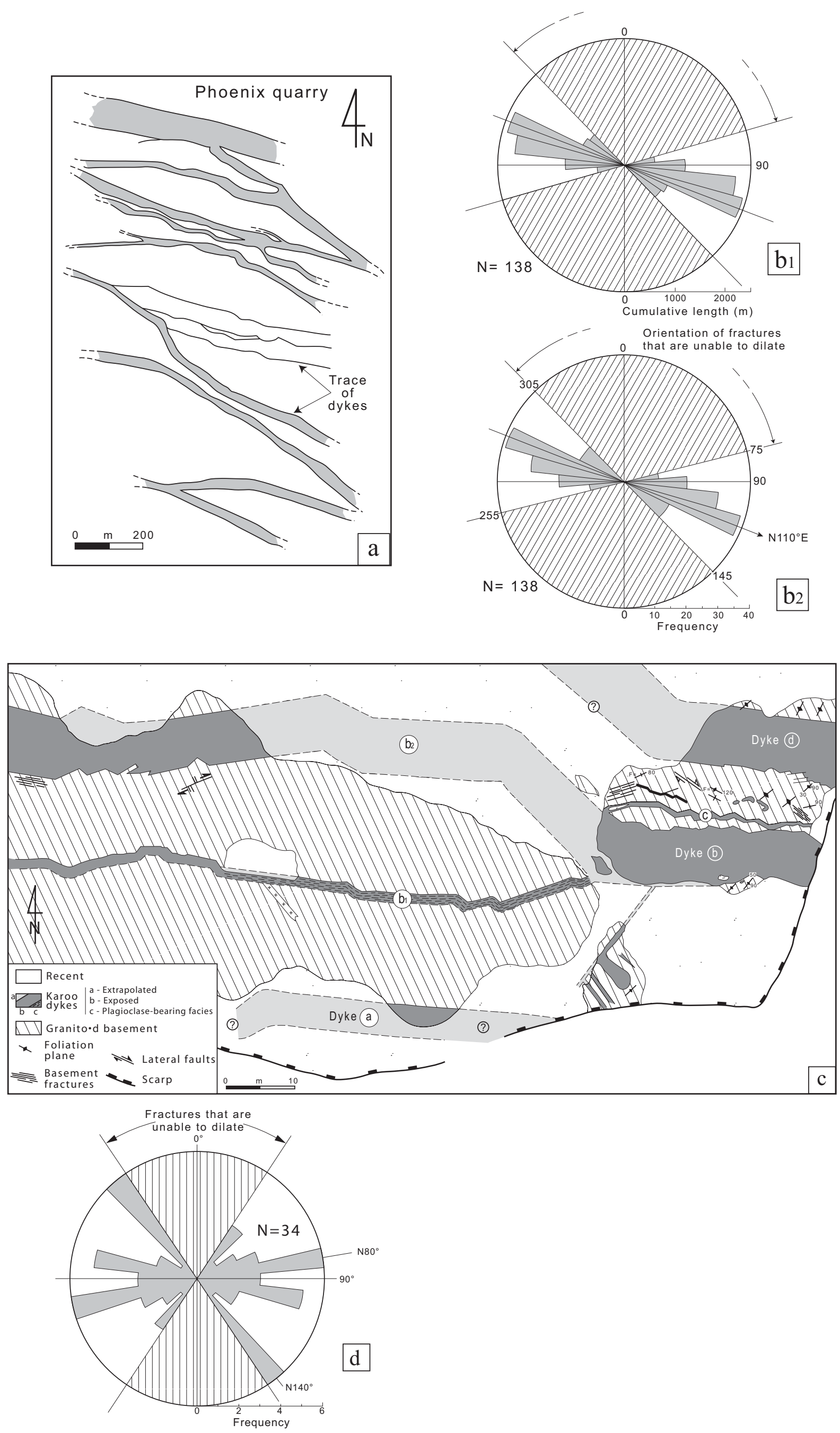


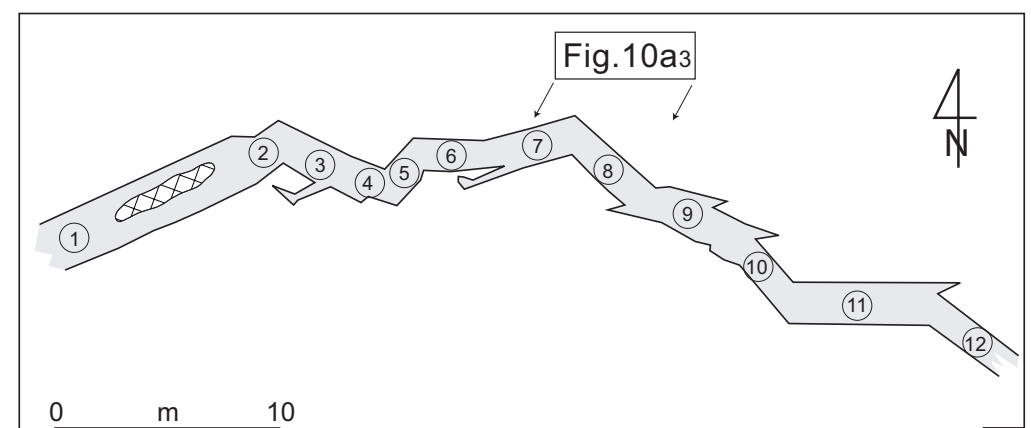

$a_{1}$

\begin{tabular}{|c|c|c|c|c|c|c|c|c|c|c|c|c|}
\hline N segment & 1 & 2 & 3 & 4 & 5 & 6 & 7 & 8 & 9 & 10 & 11 & 12 \\
\hline Strike $\left(^{\circ}\right)$ & 65 & 40 & 120 & 110 & 55 & 85 & 70 & 140 & 100 & 140 & 90 & 120 \\
\hline Width (m) & 1.8 & 1.0 & 1.0 & 1.05 & 1.25 & 1.2 & 1.35 & 1.25 & 1.35 & 1.3 & 1.3 & 1.1 \\
\hline Length (m) & 7.0 & 1.5 & 2.0 & 1.0 & 1.0 & 3.0 & 3.0 & 3.0 & 3.0 & 3.0 & 4.0 & 2.0 \\
\hline
\end{tabular}

$\mathrm{a}_{2}$
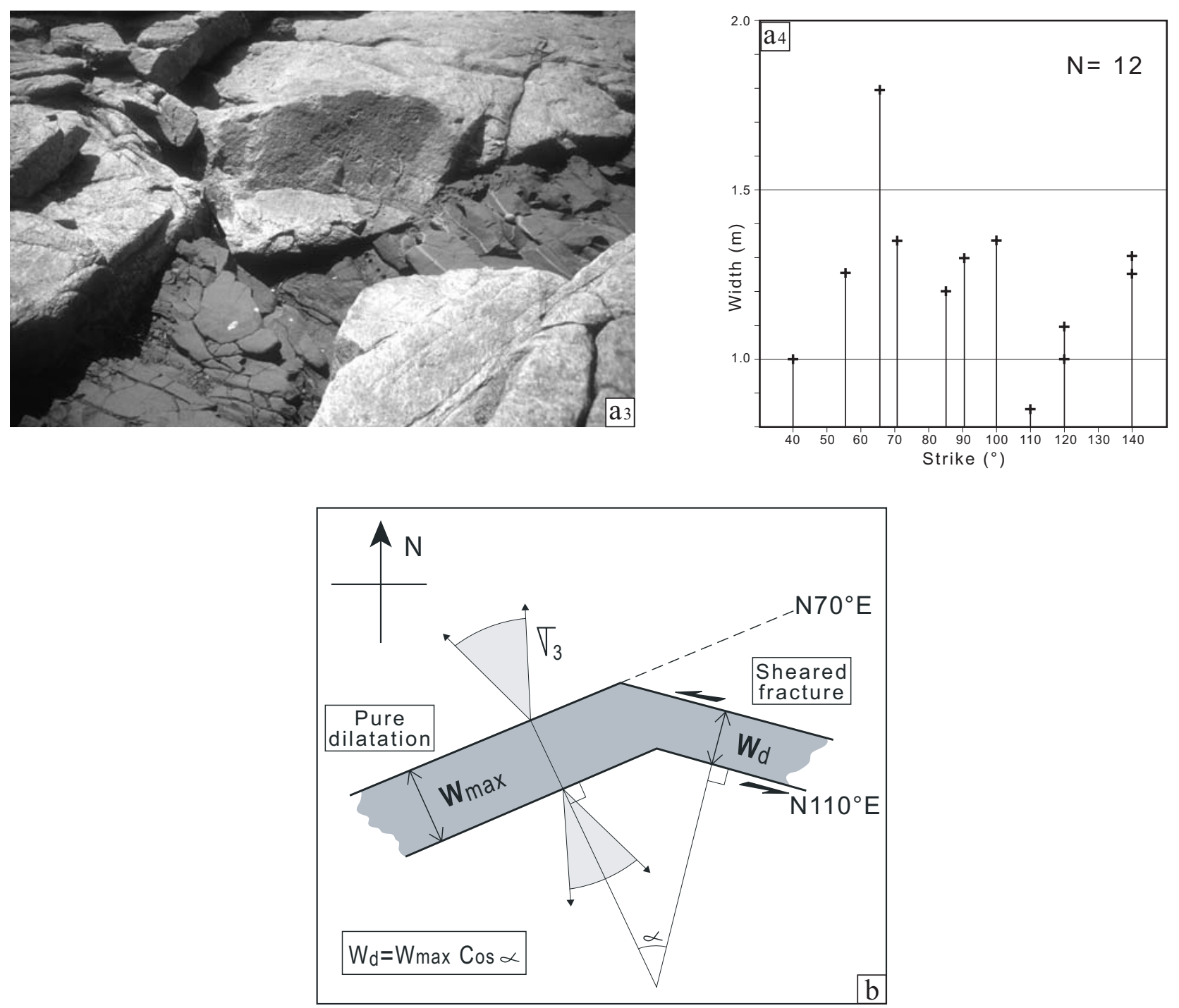


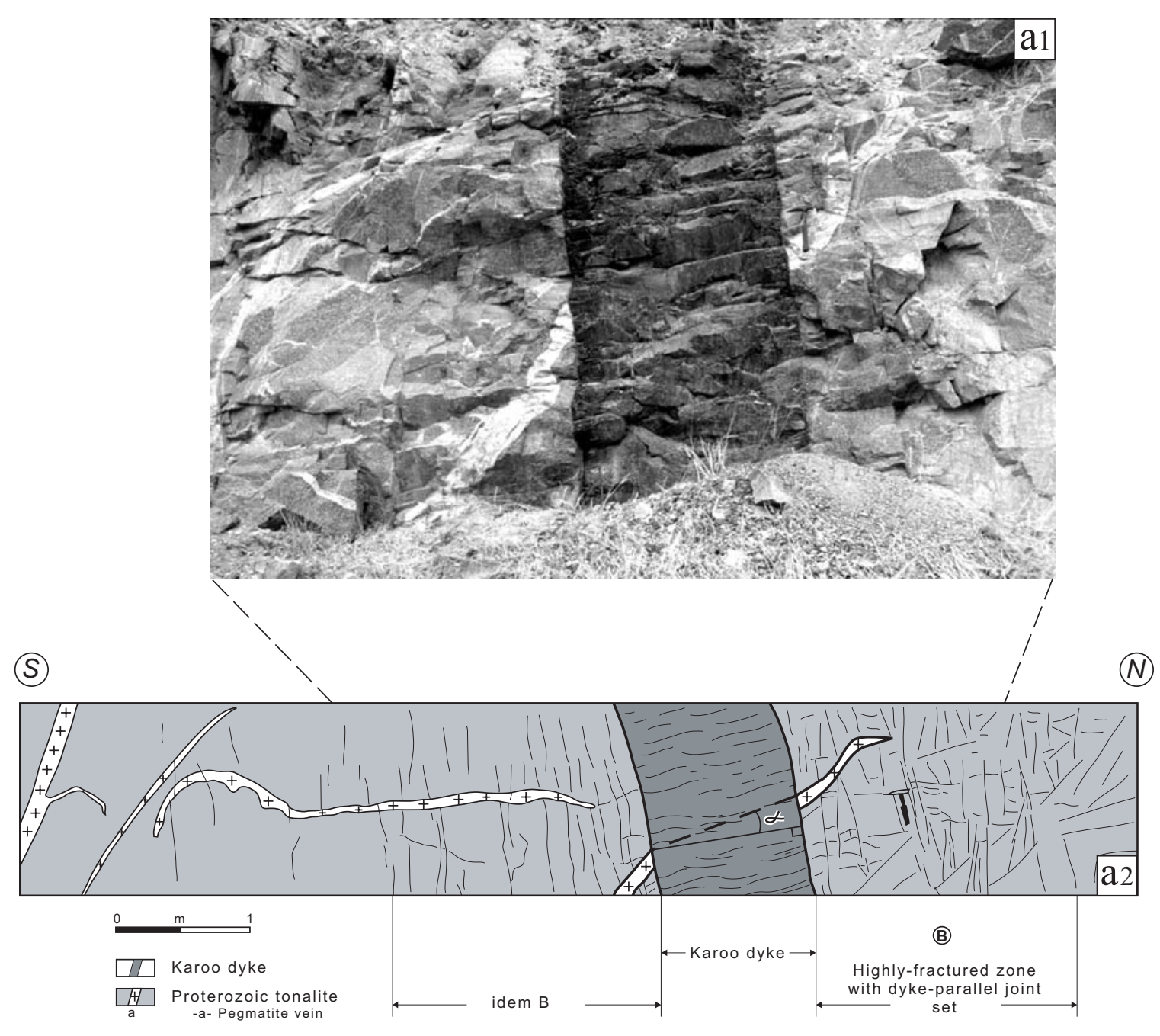



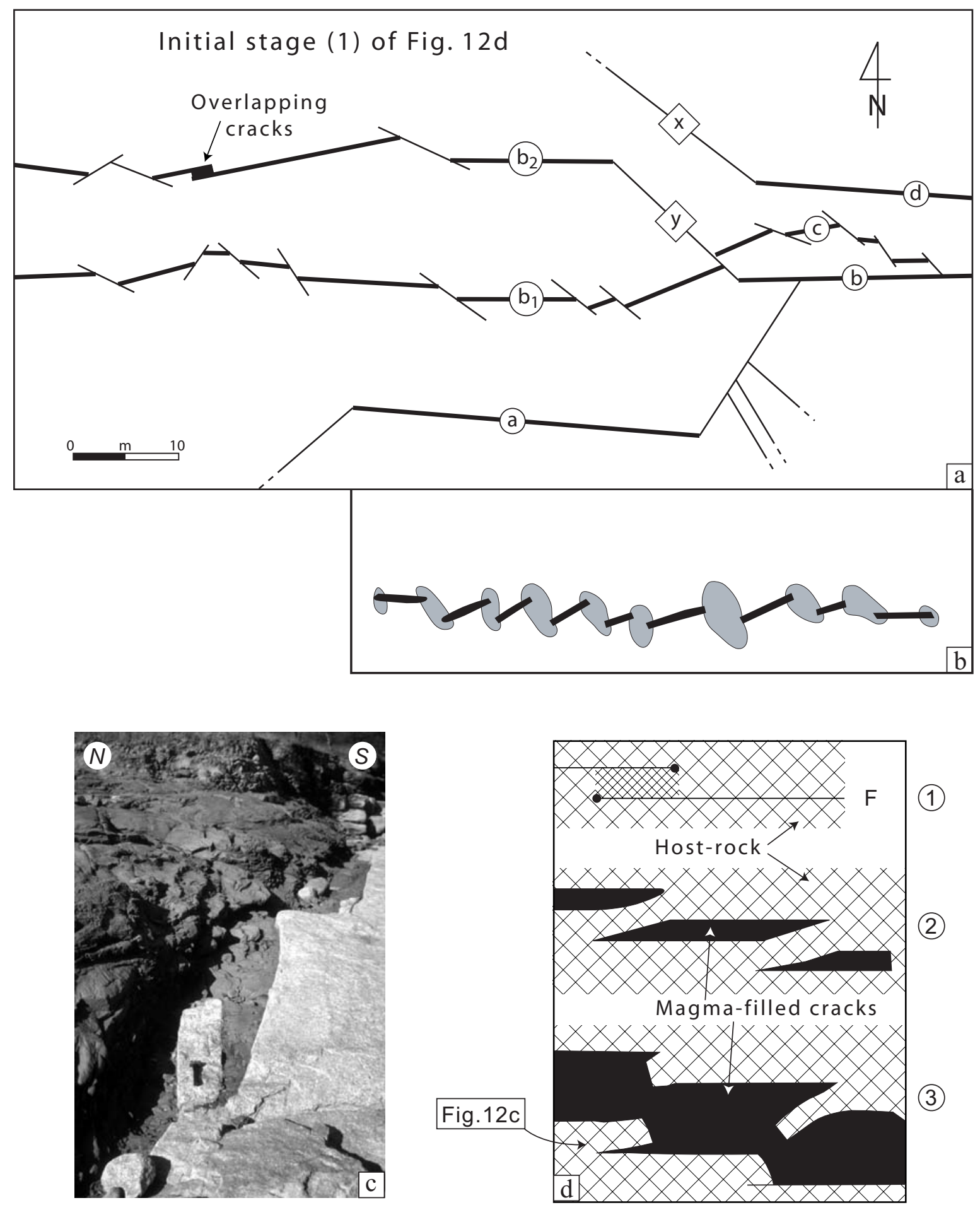

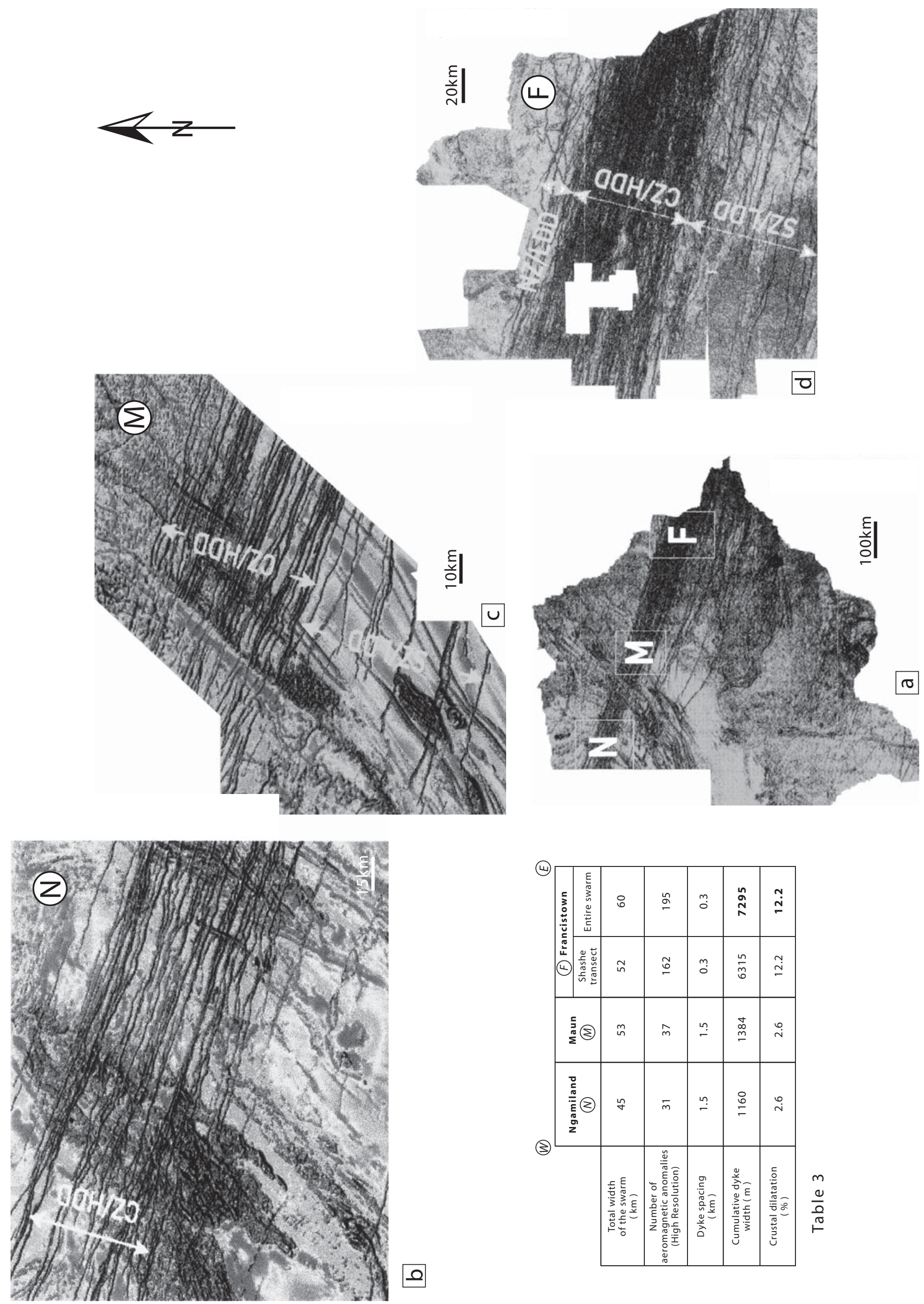

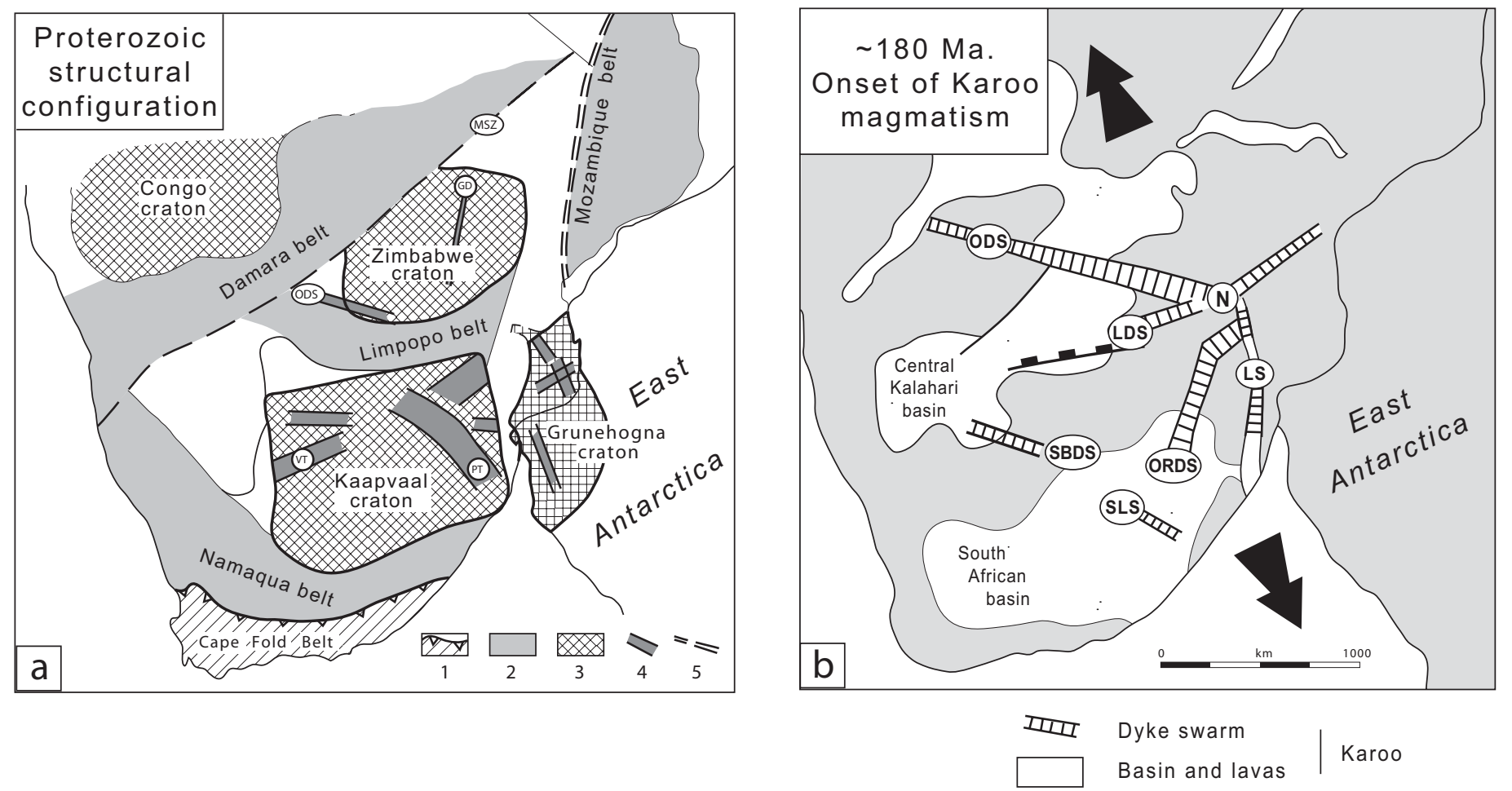


\begin{tabular}{|c|c|c|c|c|c|c|c|c|c|}
\hline & \multirow{5}{*}{\begin{tabular}{|c|} 
Geol. Survey \\
\\
46
\end{tabular}} & \multicolumn{7}{|c|}{ This work } \\
\hline & & & \multicolumn{3}{|c|}{ Field data } & & & \multirow{2}{*}{\multicolumn{2}{|c|}{$\begin{array}{c}\text { Ground magnetic data } \\
\text { Inferred age }\end{array}$}} \\
\hline & & & \multirow[t]{2}{*}{ Identified } & \multicolumn{2}{|c|}{ Measured } & \multicolumn{2}{|c|}{ Dated } & & \\
\hline & & & & Width & Complete & Karoo & Basement & Karoo & Basement \\
\hline \multirow{2}{*}{$\mathrm{N} 110_{\mathrm{i}}$} & Shashe section & & 171 & 171 & 81 & 45 & 8 & 366 & 57 \\
\hline & Thune section & $x$ & 15 & 15 & 15 & $x$ & o & no & no \\
\hline$N 70_{i}$ & Tsetsebjwe & $x$ & 14 & 14 & 0 & 1 & 1 & no & no \\
\hline
\end{tabular}

\section{Table 1}




\begin{tabular}{|c|c|c|c|c|c|c|}
\hline & \multicolumn{2}{|c|}{$\begin{array}{c}\text { Field } \\
\text { measurements }\end{array}$} & \multicolumn{2}{|c|}{$\begin{array}{c}\text { Ground } \\
\text { magnetic records }\end{array}$} & \multicolumn{2}{|c|}{$\begin{array}{c}\text { Ground magnetic } \\
+ \text { Field }\end{array}$} \\
\hline & $\begin{array}{l}\text { Number } \\
\text { of data }\end{array}$ & $\begin{array}{c}\text { Mean } \\
\text { width }(\mathrm{m})\end{array}$ & $\begin{array}{l}\text { Number } \\
\text { of data }\end{array}$ & $\begin{array}{c}\text { Mean } \\
\text { width (m) }\end{array}$ & $\begin{array}{l}\text { Number } \\
\text { of data }\end{array}$ & $\begin{array}{c}\text { Mean } \\
\text { width }(\mathrm{m})\end{array}$ \\
\hline $\begin{array}{c}\text { Total } \\
\text { population }\end{array}$ & 146 & 17.6 & 423 & $\begin{array}{c}17.5 \\
\text { S.d }=11.6\end{array}$ & & \\
\hline $\begin{array}{c}\text { Segment I } \\
(100 \% \text { karoo dykes) }\end{array}$ & 30 & 18.7 & 87 & $\begin{array}{c}12.8 \\
\text { S.d }=9.4\end{array}$ & $\begin{array}{c}87 \\
\text { (G.m) }\end{array}$ & \\
\hline $\begin{array}{c}\text { Segment II } \\
\text { (100\% karoo dykes) }\end{array}$ & 5 & 18.0 & 57 & $\begin{array}{c}21.8 \\
\text { S.d }=10.4\end{array}$ & $\begin{array}{c}57 \\
\text { (G.m) }\end{array}$ & \\
\hline $\begin{array}{c}\text { Segment III } \\
\text { (70\% karoo dykes) }\end{array}$ & $?$ & $?$ & $?$ & $?$ & $\begin{array}{c}9 \\
(\mathrm{~F})\end{array}$ & \\
\hline $\begin{array}{c}\text { Segment IV } \\
\text { (100\% karoo dykes) }\end{array}$ & 30 & 17.0 & 92 & $\begin{array}{c}18.0 \\
\text { S.d }=12.0\end{array}$ & $\begin{array}{c}92 \\
(\mathrm{G} . \mathrm{m})\end{array}$ & \\
\hline $\begin{array}{l}\text { Karoo dated } \\
\text { samples }\end{array}$ & 46 & 20.0 & & & & \\
\hline $\begin{array}{l}\text { Total population } \\
\text { of karoo dykes }\end{array}$ & 9 & & $\begin{array}{c}I+I I+I V \\
236\end{array}$ & & 245 & $\begin{array}{c}16.48 \\
S . d=11.30\end{array}$ \\
\hline
\end{tabular}




\begin{tabular}{|c|c|c|c|}
\hline $\begin{array}{c}\text { Tectono-magmatic } \\
\text { setting }\end{array}$ & Age & $\begin{array}{l}\text { Mean dyke } \\
\text { width }(\mathrm{m})\end{array}$ & Reference \\
\hline \multirow{4}{*}{\begin{tabular}{l|l} 
BTIP & $\begin{array}{l}\text { Skye } \\
\text { Mull }\end{array}$ \\
Iceland Rifted Zone
\end{tabular}} & Paleocene & 0.6 & Walker 1993 \\
\hline & Paleocene & 1.2 & Jolly \& Sanderson 1995 \\
\hline & Quaternary & $<2.0$ & Gudmundsson 1990 \\
\hline & Tertiary & 4.0 & " " " " \\
\hline Central Atlantic Ridge & Present & 1.0 & Karson et al. 1999 \\
\hline Hawai & Present & 0.7 & Walker 1987 \\
\hline Mid-Oceanic Ridge & Num. model. & $0.2<W<3.0$ & Head et al. 1996 \\
\hline Oman Ophiolite & Permo-Trias & $<1.0$ & Lippard et al.1986 \\
\hline \multirow{4}{*}{\begin{tabular}{l|l}
\multicolumn{2}{l}{ Giant Okavango D.S. } \\
Mc Kenzie D.S. & Baranga \\
(world's & Carlton \\
greatest D.S.) & Duluth
\end{tabular}} & Middle Jur. & 16.50 & This work \\
\hline & Archanan & $<30$ & Anderson \& Dith 1982 \\
\hline & Arcnaean & $<15$ & Chandler 1986 \\
\hline & $(1.2 \mathrm{Ga})$ & 4 & Motamedi 1982 \\
\hline
\end{tabular}

Table 3 